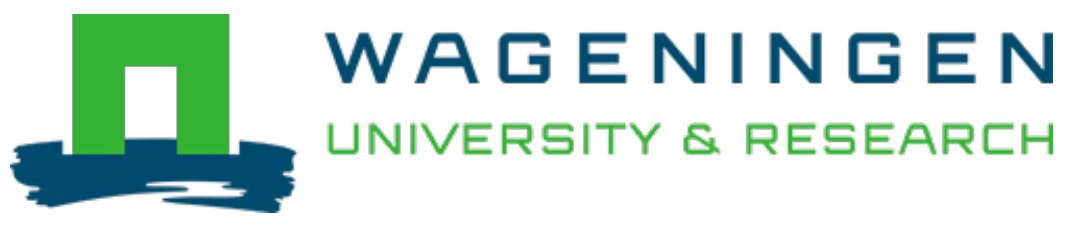

\title{
Baobab food products: a review on their composition and nutritional value
}

Critical Reviews in Food Science and Nutrition

Chadare, F.J.; Linnemann, A.R.; Hounhouigan, J.D.; Nout, M.J.R.; Boekel, M.A.J.S.

https://doi.org/10.1080/10408390701856330

This publication is made publicly available in the institutional repository of Wageningen University and Research, under the terms of article $25 \mathrm{fa}$ of the Dutch Copyright Act, also known as the Amendment Taverne. This has been done with explicit consent by the author.

Article $25 \mathrm{fa}$ states that the author of a short scientific work funded either wholly or partially by Dutch public funds is entitled to make that work publicly available for no consideration following a reasonable period of time after the work was first published, provided that clear reference is made to the source of the first publication of the work.

This publication is distributed under The Association of Universities in the Netherlands (VSNU) 'Article $25 \mathrm{fa}$ implementation' project. In this project research outputs of researchers employed by Dutch Universities that comply with the legal requirements of Article $25 \mathrm{fa}$ of the Dutch Copyright Act are distributed online and free of cost or other barriers in institutional repositories. Research outputs are distributed six months after their first online publication in the original published version and with proper attribution to the source of the original publication.

You are permitted to download and use the publication for personal purposes. All rights remain with the author(s) and / or copyright owner(s) of this work. Any use of the publication or parts of it other than authorised under article $25 \mathrm{fa}$ of the Dutch Copyright act is prohibited. Wageningen University \& Research and the author(s) of this publication shall not be held responsible or liable for any damages resulting from your (re)use of this publication.

For questions regarding the public availability of this publication please contact openscience.library@,wur.nl 


\title{
Baobab Food Products: A Review on their Composition and Nutritional Value
}

\author{
F. J. CHADARE, ${ }^{1,2}$ A. R. LINNEMANN, ${ }^{2}$ J. D. HOUNHOUIGAN, ${ }^{1}$ M. J. R. NOUT, ${ }^{2}$ \\ and M. A. J. S. VAN BOEKEL ${ }^{2}$ \\ ${ }^{1}$ Faculty of Agronomic Sciences, University of Abomey-Calavi, Cotonou, Benin \\ ${ }^{2}$ Department of Agrotechnology and Food Sciences, Wageningen University, Wageningen, The Netherlands
}

\begin{abstract}
Several authors have published about baobab food products. Data on macronutrients, micronutrients, amino acids, and fatty acids were collected from literature for pulp, leaves, seeds, and kernels of the baobab tree. The results show that baobab pulp is particularly rich in vitamin C; consumption of $40 \mathrm{~g}$ covers 84 to more than $100 \%$ of the Recommended Daily Intake (RDI) of pregnant women (19-30 years). The leaves are particularly rich in calcium (307 to $2640 \mathrm{mg} / 100 \mathrm{~g} d w$ ), and they are known to contain good quality proteins with a chemical score of 0.81. The whole seeds and the kernels have a relatively high lipid content, 11.6 to $33.3 \mathrm{~g} / 100 \mathrm{~g} d w$ and 18.9 to $34.7 \mathrm{~g} / 100 \mathrm{~g} \mathrm{dw}$, respectively. The pulp and leaves exhibit antioxidant properties with a higher activity in the pulp than in the leaves. Reported nutrient contents of different baobab parts show a large variation, which may have arisen from various factors. Three recommendations are given for future research: 1. More attention should be given to accuracy and precision of analytical methods, 2. Research about digestibility and bioavailability of baobab products is needed, 3. The effect of storage and processing on the nutritional value of baobab products needs to be assessed.
\end{abstract}

Keywords nutrients, antioxidant capacity, baobab pulp, baobab leaves, baobab seeds, baobab kernels

\section{INTRODUCTION}

The African baobab tree (Adansonia digitata) and its related species belong to the family of Malvacea (Alverson et al., 1999). The tree occurs naturally in dry areas of Africa, mainly in the Sahelian, Soudano-Sahelian, and Soudanian zones; the distribution extends through the woodlands, savannas, and grasslands of subSaharan Africa to about $25^{\circ} \mathrm{S}$. It is characterized by its massive size, reaching to a height of $18-25 \mathrm{~m}$. Crown shape ranges from depressed ovoid through globose to obovoid. The bark is smooth, reddish-brown, greyish-brown or purplish-grey, soft, and fibrous. Leaves are 2-3 foliate at the start of the season and they are early deciduous; more mature ones are 5-7(-9) foliate. Leaves of young trees are often simple. They are glabrous to tomentose; the former are preferred for food. The fruits are very variable, usually globose to ovoid but sometimes oblong-cylindrical, often irregular in shape, apex pointed, or obtuse, covered by velvety yellowish or greenish hairs (Sidibe and Williams, 2002).

Address correspondence to A. R. Linnemann, Department of Agrotechnology and Food Sciences, PO Box 8129, 6700 EV Wageningen, The Netherlands. E-mail: anita.linnemann@wur.nl
The fruits are indehiscent; they are broken open by chimpanzees, baboons, etc. or will crack open if they fall on a stony surface. They contain reniform seeds and powdery pulp (Baum, 1995).

The baobab is a multi-purpose tree with products having numerous food uses and medicinal properties, and a fibrous bark that is used for various applications (Sidibe and Williams, 2002; Codjia et al., 2001; Wickens, 1982). The pulp of the fruit, the seeds, and the leaves are all utilized and are essentially wildgathered foods. They are consumed daily by rural populations in Africa and are also commercialized. The tuberous taproot of seedlings and young saplings are also eaten, especially in times of famine. Baobab products (leaves, fruits, craft products, and bark) are sold on local, informal markets. Middlemen also operate and trade in the larger urban markets (Sidibe and Williams, 2002). In Benin, for instance, $6923 \mathrm{~kg}$ of pulp was sold for about 1370 euros in a rural market of Boukoumbe district in northern Benin by 48 vendors in the period from January to March 2001 (Codjia et al., 2003). In developed countries, e.g., Italy, baobab fruits are used to produce dietary supplements and cosmetics.

Previously published biochemical analyses revealed that baobab's edible parts (pulp, leaves, seeds) are rich in nutrients (Sidibe and Williams, 2002; Codjia et al., 2001; Yazzie et al., 
1994; Sena et al., 1998; Nordeide et al., 1996; Barminas et al., 1998; Sidibe et al., 1996). Literature reviews on baobab by Sidibe and Williams (2002) and Diop et al. (2005) provide substantial information on the species taxonomy, distribution, properties, utilization, agronomy, and agroecology. However, these reviews did not deal in detail with the nutritional value of baobab food products. Information on the nutrient composition of food is essential to estimate adequate nutrient intake both at individual and group levels (Joyanes and Lema, 2006). The present review investigates the nutritional value of baobab food products based on data from various authors and critically evaluates the similarities and divergences of the values in relation to the research methods used. Research needs are identified on the basis of our review. For each component, the reported values are, as much as possible, converted into the same unit, and their average, minimum, and maximum values are calculated and reported in Table 1 . Nonconverted data are shown as reported originally.

\section{LEAVES}

\section{Macronutrients}

Nordeide et al. (1996) and Lockett et al. (2000) found that the water content (Table 1) of dried baobab leaves was 6.4 and $8.2 \%$, respectively. The average water content is then $7.3 \%$. Oomen and Grubben (1978) investigated the moisture content of fresh leaves and found a value of $77 \%$. The reported energy value varies from $1180 \mathrm{~kJ} / 100 \mathrm{~g} \mathrm{dw}$ (Becker, 1983) to $1580.6 \mathrm{~kJ} / 100 \mathrm{~g}$ $\mathrm{dw}$ (Nordeide et al., 1996) with an average of $1380.3 \mathrm{~kJ} / 100 \mathrm{~g}$. The carbohydrate content varies from $40 \mathrm{~g} / 100 \mathrm{~g} \mathrm{dw}$ (Lockett et al., 2000) to $69 \mathrm{~g} / 100 \mathrm{~g} \mathrm{dw}$ (Nordeide et al., 1996); the average is $56.4 \mathrm{~kJ} / 100 \mathrm{~g}$. Crude protein contents vary from $10 \mathrm{~g} / 100 \mathrm{~g}$ $\mathrm{dw}$ (Yazzie et al., 1994; Lockett et al., 2000) to $14.9 \mathrm{~g} / 100 \mathrm{~g}$ $\mathrm{dw}$ (Nordeide et al., 1996). The reported values for fat content are generally low and vary from $4 \mathrm{~g} / 100 \mathrm{~g} \mathrm{dw}$ (Becker, 1983) to $6.3 \mathrm{~g} / 100 \mathrm{~g} \mathrm{dw}$ (Lockett et al., 2000). The ash content ranges from $11.5 \mathrm{~g} / 100 \mathrm{~g} \mathrm{dw}$ (Nordeide et al., 1996) to $15.9 \mathrm{~g} / 100 \mathrm{~g} \mathrm{dw}$ (Lockett et al., 2000).

The variability in the reported values for baobab leaves is lower than for the macronutrient composition of the pulp, despite the use of different measurement methods by the authors. The time-temperature combination used to determine water and ash contents were different. Energy was calculated using Atwaters' coefficients while carbohydrates were determined by difference. The fat content was determined either by the Soxtec system or gravimetrically, while the protein content was determined by Kjeldahl analysis. However, the number of authors who investigated the macronutrient composition of the leaves, is rather low.

\section{Minerals}

Baobab leaves are very rich in calcium according to literature (Table 1). With an average of $1582.3 \mathrm{mg} / 100 \mathrm{~g} \mathrm{dw}$, the reported values range between $1470 \mathrm{mg} / 100 \mathrm{~g} \mathrm{dw}$ (Sena et al., 1998) and $2640 \mathrm{mg} / 100 \mathrm{~g} \mathrm{dw}$ (Yazzie et al., 1994). However, lower values of 307 and $315 \mathrm{mg} / 100 \mathrm{~g} \mathrm{dw}$ were mentioned by Yazzie et al. (1994), who studied different specimens of baobab leaves. Boukari et al. (2001) also measured the Ca content of selected African foods and mentioned that baobab dried leaves contain $2240 \mathrm{mg} / 100 \mathrm{~g} \mathrm{dw}$; among the 24 foods analyzed, baobab was ranked fifth after sorrel leaves (Hibiscus sabdariffa) $(3630 \mathrm{mg} / 100 \mathrm{~g} \mathrm{dw})$, amaranth (Amaranthus spp.) leaves (3590 mg/100 g dw), okra (Abelmoschu esculentus) leaves (2850 $\mathrm{mg} / 100 \mathrm{~g} \mathrm{dw}$ ), and onion (Allium cepa) leaves $(2540 \mathrm{mg} / 100 \mathrm{~g}$ $\mathrm{dw})$. The reported magnesium content ranges from $93.6 \mathrm{mg} / 100$ $\mathrm{g} \mathrm{dw}$ (Smith et al., 1996) to $549 \mathrm{mg} / 100 \mathrm{~g} \mathrm{dw}$ (Glew et al., 1997). Smith et al. (1996) investigated the mineral content of dark, fine light, and rough light leaves and found a large variability in $\mathrm{Mg}$ content $(93.6 \mathrm{mg} / 100 \mathrm{~g} \mathrm{dw}$ for the dark leaves, $121.7 \mathrm{mg} / 100 \mathrm{~g} \mathrm{dw}$ for the fine light leaves and $274.2 \mathrm{mg} / 100$ $\mathrm{g} \mathrm{dw}$ for the rough light leaves). It is presumed that the connotations "fine" and "rough," with respect to the leaves, refer to their pubescence. The potassium contents vary greatly from $140 \mathrm{mg} / 100 \mathrm{~g} \mathrm{dw}$ to $1080 \mathrm{mg} / 100 \mathrm{~g} \mathrm{dw}$ (Yazzie et al., 1994) with an average of $531 \mathrm{mg} / 100 \mathrm{~g}$. The reported sodium contents range from $3.8 \mathrm{mg} / 100 \mathrm{~g} \mathrm{dw}$ (Sena et al., 1998) to $163 \mathrm{mg} / 100$ $\mathrm{g} \mathrm{dw}$ (Glew et al., 1997); the average of the reported values is $83.4 \mathrm{mg} / 100 \mathrm{~g} \mathrm{dw}$. Smith et al. (1996) reported a copper content of $0.29 \mathrm{mg} / 100 \mathrm{~g} \mathrm{dw}$ and most of the other values are between the latter and $1.6 \mathrm{mg} / 100 \mathrm{~g} \mathrm{dw}$, which is the highest value reported by Glew et al. (1997). The manganese content varies from 1.9 to $9.8 \mathrm{mg} / 100 \mathrm{~g} \mathrm{dw}$ (Yazzie et al., 1994), and phosphorus contents range from $115 \mathrm{mg} / 100 \mathrm{~g} \mathrm{dw}$ (Lockett et al., 2000) to $875.6 \mathrm{mg} / 100 \mathrm{~g} \mathrm{dw}$ (Barminas et al., 1998). Zinc levels generally vary between $0.7 \mathrm{mg} / 100 \mathrm{~g} \mathrm{dw}$ (Smith et al., 1996) and $4.0 \mathrm{mg} / 100 \mathrm{~g} \mathrm{dw}$ (Yazzie et al., 1994). However, a higher value of $22.4 \mathrm{mg} / 100 \mathrm{~g} \mathrm{dw}$ was reported by Barminas et al. (1998). The iron content varies greatly from $1.2 \mathrm{mg} / 100 \mathrm{~g} \mathrm{dw}$ for rough leaves (Smith et al., 1996) to $100 \mathrm{mg} / 100 \mathrm{~g} \mathrm{dw}$ (Yazzie et al., 1994). The molybdenum content is generally lower than $2 \mathrm{mg} / 100 \mathrm{~g} \mathrm{dw}$.

Lockett et al. (2000) used atomic absorption spectroscopy to determine most elements except P, whereas Sena et al. (1998) and Glew et al. (1997) used inductively coupled argon plasma atomic emission spectroscopy. Barminas et al. (1998) and Nordeide et al. (1996) used atomic absorption spectrophotometry, Smith et al. (1996) atomic absorption and Yazzie et al. (1994) atomic emission spectrophotometry.

The structure and the color of the leaves seem to be related to the mineral content (Smith et al., 1996). This apparent relation requires further investigation. Moreover, in future research better descriptions of analyzed leaf material are required to allow comparison.

To our knowledge, the bioavailability of these minerals has not been investigated. However, this is necessary to determine to which extent baobab leaves can be used to combat certain micronutrient deficiency problems. 


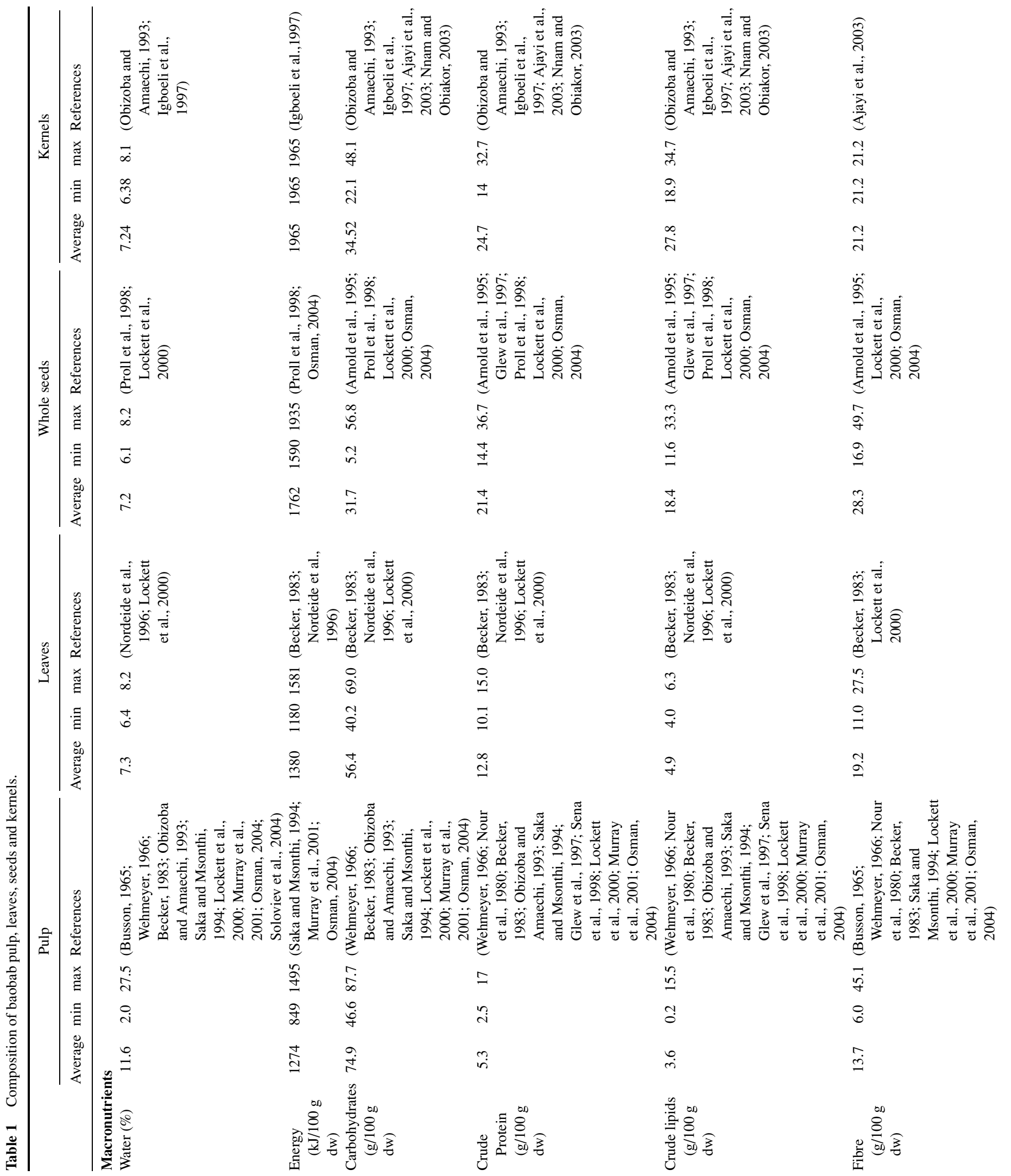



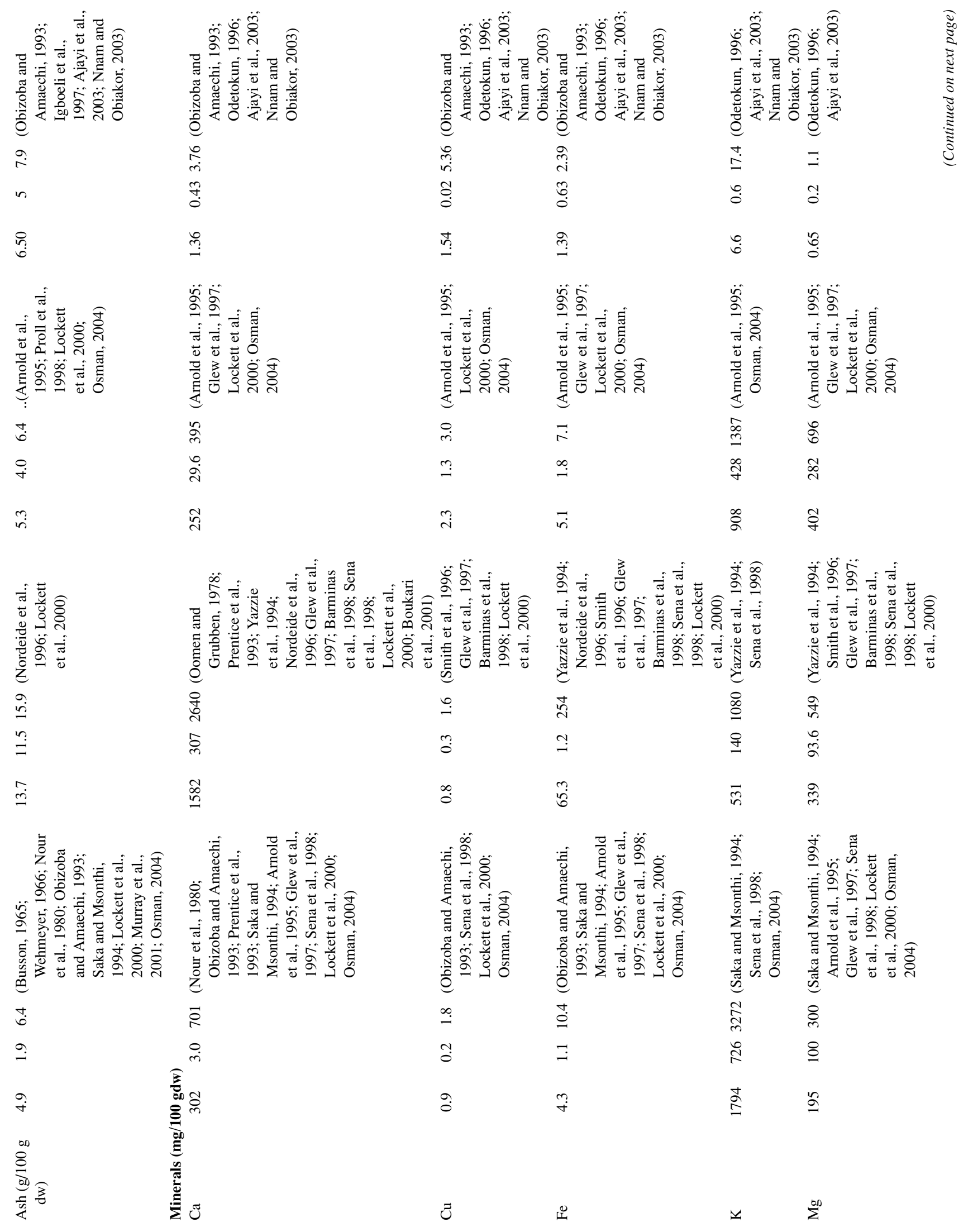


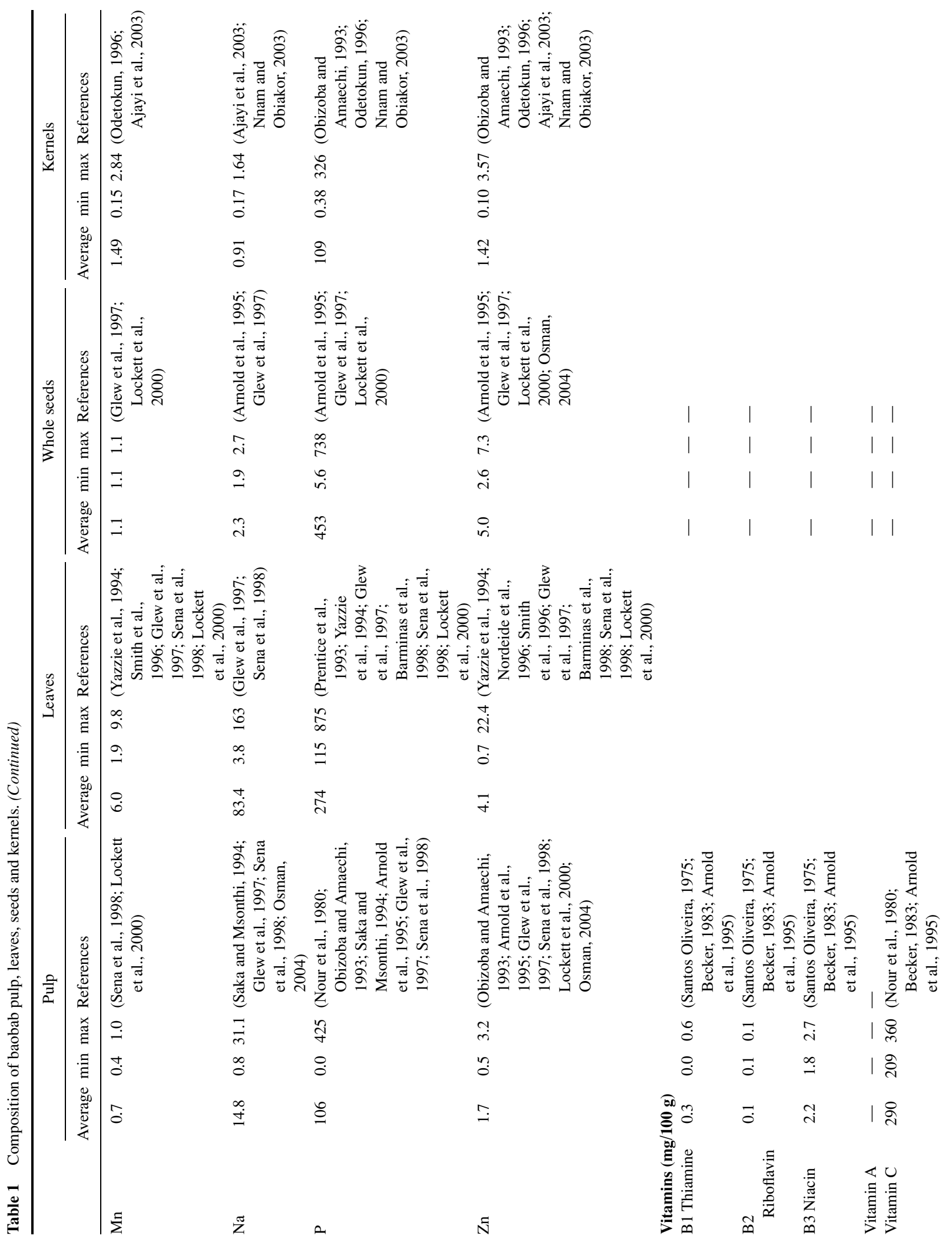




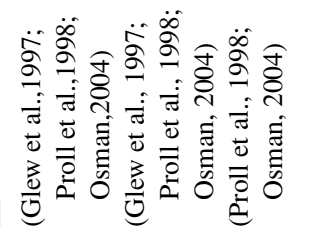

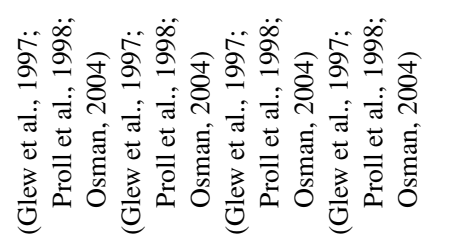

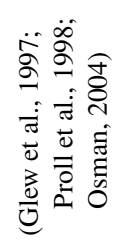

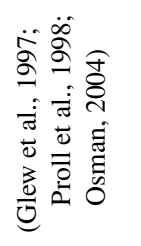

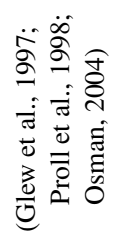

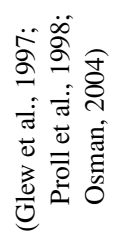

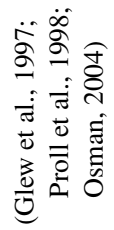

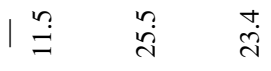

$\dot{5}=\stackrel{3}{9}$

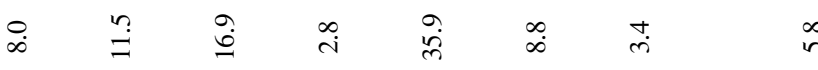

$\stackrel{\infty}{\stackrel{D}{\infty}}$

i.

更

ल

$\stackrel{\circ}{\stackrel{0}{1}} \stackrel{9}{2}$

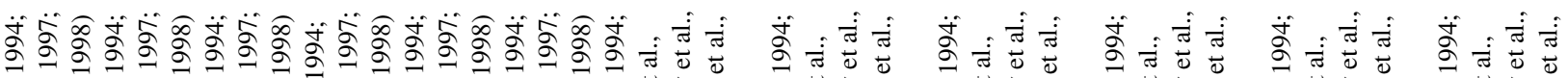

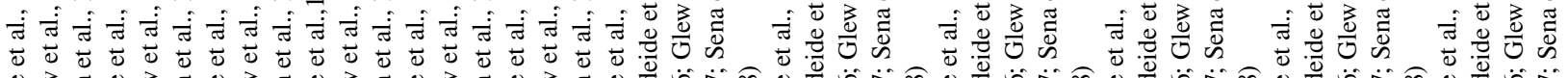

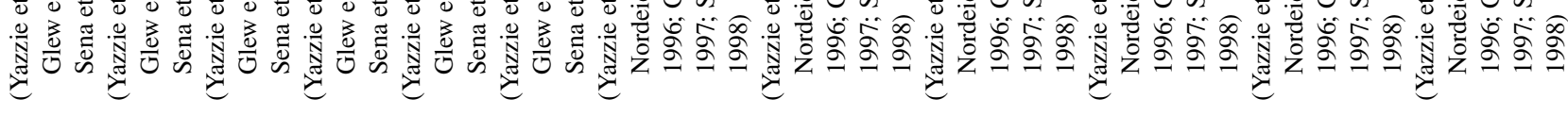

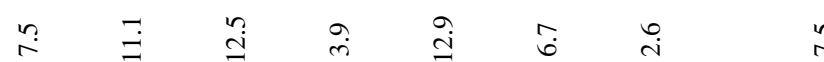

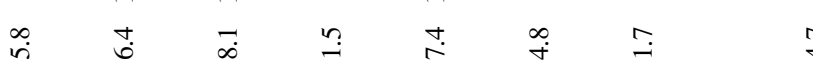

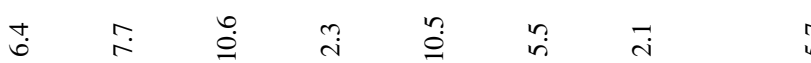

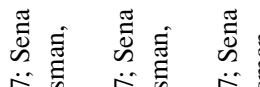

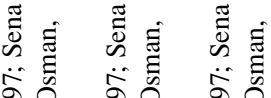

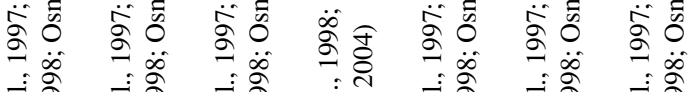

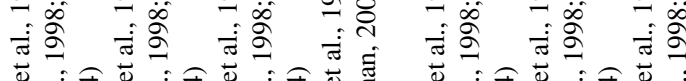

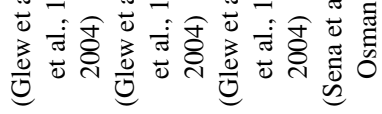

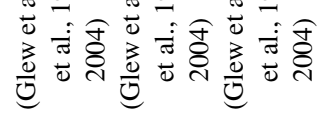

$\frac{1}{2}$

$\frac{1}{4}$

is 2

$\infty$

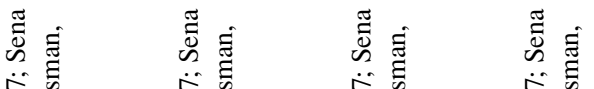

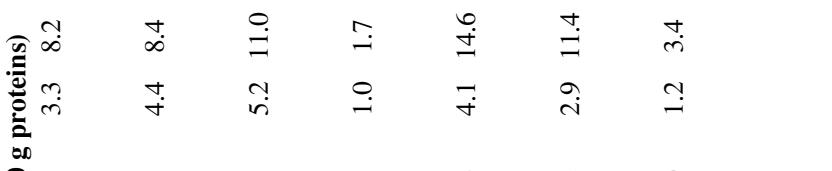

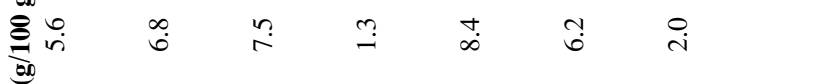

|n!n!n!

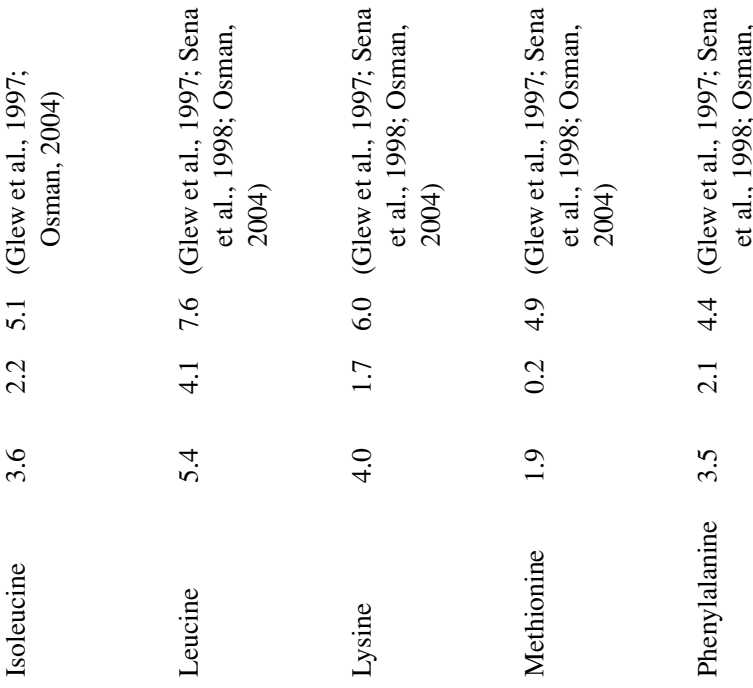




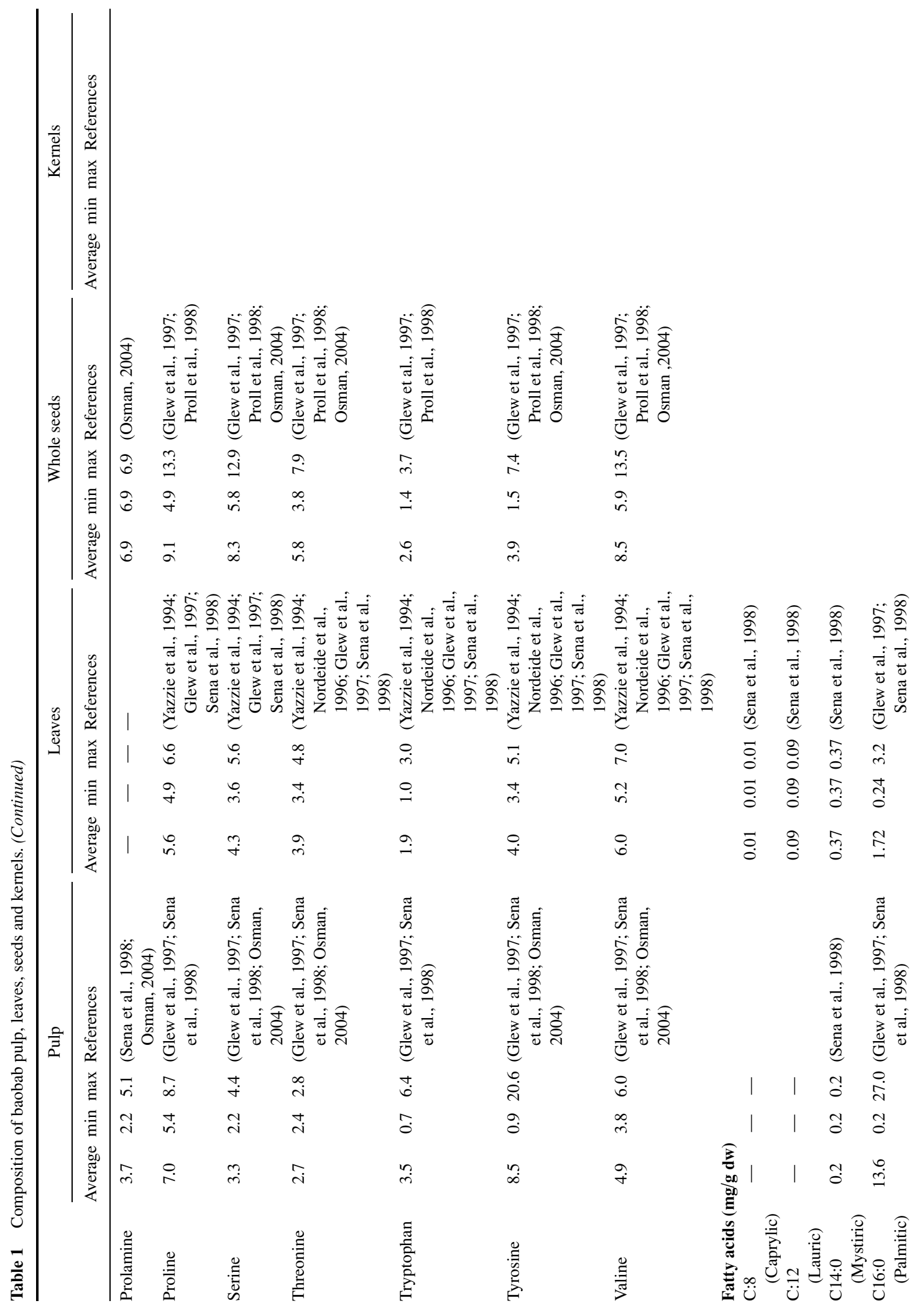




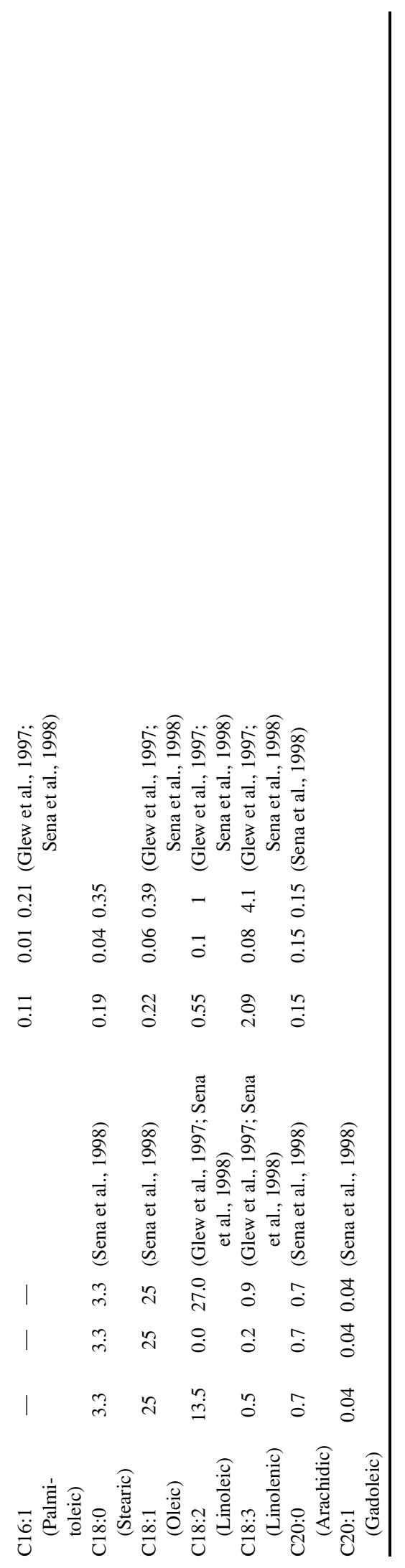


Table 2 Vitamin A contents of baobab leaves

\begin{tabular}{|c|c|c|c|c|c|c|}
\hline \multirow[b]{2}{*}{ Leaves } & \multicolumn{3}{|c|}{ Sun dried } & \multicolumn{3}{|c|}{ Shade dried } \\
\hline & $\begin{array}{c}\alpha \text { carotene } \\
(\mu \mathrm{g} / \mathrm{g})\end{array}$ & $\begin{array}{c}\beta \text { carotene } \\
(\mu \mathrm{g} / \mathrm{g})\end{array}$ & $\begin{array}{c}\text { Retinol } \\
\text { equivalent } \\
(\mu \mathrm{g} / \mathrm{g})\end{array}$ & $\begin{array}{c}\alpha \text { carotene } \\
(\mu \mathrm{g} / \mathrm{g})\end{array}$ & $\begin{array}{c}\beta \text { carotene } \\
(\mu \mathrm{g} / \mathrm{g})\end{array}$ & $\begin{array}{c}\text { Retinol } \\
\text { equivalent } \\
(\mu \mathrm{g} / \mathrm{g})\end{array}$ \\
\hline Young trees, small leaves & 5.7 & 74.5 & 12.9 & 12.9 & 156 & 27.2 \\
\hline Young trees, large leaves & 6.7 & 54.0 & 9.3 & 5.1 & 130 & 22.0 \\
\hline Old trees, small leaves & 9.9 & 87.0 & 15.3 & 19.4 & 147 & 26.2 \\
\hline Old trees, large leaves & 4.1 & 69.0 & 11.5 & 7.1 & 107 & 18.5 \\
\hline
\end{tabular}

Source: Scheuring et al. (1999).

\section{Vitamins}

Only few authors have investigated the vitamin A content of baobab leaves. Scheuring et al. (1999) found that the simple practice of drying baobab leaves in the shade protects against deterioration of provitamin A. The selection of small leaves (which is tree specific) further increased provitamin A by $20 \%$. The combination of small leaves and shade drying enabled the retention of the provitamin A content up to $27 \mu \mathrm{g}$ retinol equivalent per gram of dried leaf powder (Table 2). Other authors mention the carotenoid content of baobab leaves (Table 3). Vertuani et al. (2002) found that baobab leaves have an Integral Antioxidant Capacity (IAC) of $8.7 \mathrm{mmol} / \mathrm{g}$. The IAC represents the sum of the antioxidant capacity of hydrophilic and lipophilic antioxidants, calculated as mmol equivalents in activity of Trolox, determined in the best experimental conditions for the sample. The antioxidant activity may be due to the presence of carotenoids or other phenolic compounds, but this needs to be checked.

The type of leaves analyzed, young or old, sun or shade dried, is not indicated by Sena et al. (1998) and Nordeide et al. (1996) and their reported values are far below the general range of the ones reported by Scheuring et al. (1999). Becker (1983) reported thiamine, riboflavin, and niacin content of $0.13,0.82$, and $8.06 \mathrm{mg} / 100 \mathrm{~g} \mathrm{dw}$, respectively.

\section{Amino Acids}

Concerning the amino acid content, the highest averages from the reported values were found for aspartic acid $(10.6 \mathrm{~g} / 100 \mathrm{~g}$ protein), glutamic acid (10.5 g/100 g protein), leucine ( $8.3 \mathrm{~g} / 100$ g protein), and arginine ( $7.7 \mathrm{~g} / 100 \mathrm{~g}$ protein), whereas the lowest

Table 3 Carotenoid contents of baobab leaves

\begin{tabular}{|c|c|c|c|c|}
\hline Authors & Lutein & $\alpha$-Carotene & $\beta$-carotene & $\begin{array}{r}\text { Vitamin A } \\
\text { total Retino } \\
\text { equivalent }\end{array}$ \\
\hline $\begin{array}{l}\text { Sena et al. } 1998(\mu \mathrm{g} / \mathrm{g} \\
\text { dw) (Niger) }\end{array}$ & 50.9 & 0.92 & 17.2 & \\
\hline $\begin{array}{l}\text { Nordeide et al., } 1996 \\
\quad(\mu \mathrm{g} / 100 \mathrm{~g})(\text { Mali })\end{array}$ & & trace & 670 & 112 \\
\hline $\begin{array}{l}\text { Nordeide et al., } 1996 \\
(\mu \mathrm{g} / \mathrm{g})^{*}\end{array}$ & & & 6.7 & 1.12 \\
\hline
\end{tabular}

${ }^{*}$ Converted values. values were found for methionine $(1.7 \mathrm{~g} / 100 \mathrm{~g}$ protein) and tryptophan (1.9 g/100 g protein) (Table 1). Nordeide et al. (1996) mentioned that the limiting amino acid for baobab leaf products is lysine. The authors also computed the chemical score (FAO/WHO/UNU, 1985) using the reference amino acid pattern for preschool children (2-5 years) and found that it was $81 \%$ for baobab leaves. The amino acid chemical score should be in the order of 60 and above (Nordeide et al., 1996). This implies that the leaves of $A$. digitata are potentially valuable protein sources to be used to complement the amino acid profile of local dishes, namely in order to improve the protein quality of agricultural products that are not deficient in lysine, e.g., cereals. Similarly, Yazzie et al. (1994) calculated the chemical score using tryptophan, the most limiting essential amino acid and found that baobab leaf contains significant amounts of all the essential amino acids. The variation in the reported amino acid contents is relatively low between authors, and also between different specimens analyzed by the same author. A comparison with other forest leaves showed that the chemical scores of Tamarindus indica dried leaves, Parkia biglobosa, Amaranthus viridis dried leaves, and Allium cepa dried leaves are $79 \%, 61 \%, 51 \%$, and $47 \%$, respectively (Nordeide et al., 1996).

\section{Fatty Acids}

Few authors investigated the fatty acid content of baobab leaves, and the reported data by Sena et al. (1998) and Glew et al. (1997) show many differences. The leaves mainly seem to contain oleic and palmitic acid.

\section{Antinutrients}

Baobab leaves contain some toxicants (Andy and Eka, 1985). Phytic acid content varies from $0.04 \mathrm{mg} / 100 \mathrm{~g}$ in market samples to $0.05 \mathrm{mg} / 100 \mathrm{~g}$ in field samples. Total oxalic acid ranges from $4.37 \mathrm{mg} / 100 \mathrm{~g}$ in field samples (with $40 \%$ soluble oxalate) to $5.26 \mathrm{mg} / 100 \mathrm{~g}$ in market samples (with $37 \%$ soluble oxalate). Baobab leaves contain also $37.2 \mathrm{~g} / 100 \mathrm{~g}$ (market samples) to $40.4 \mathrm{mg} / 100 \mathrm{~g}$ (field samples) hydrocyanic acid. Tannins levels are $17.8 \mathrm{mg} / 100 \mathrm{~g}$ and $19.8 \mathrm{mg} / 100 \mathrm{~g}$ in market samples and field samples, respectively. These values are below the known toxic 
levels but may interfere with the nutrients and possibly decrease their digestibility and availability (Andy and Eka, 1985).

\section{THE PULP}

\section{Macronutrients}

\section{Water}

The reported water content (Table 1) varies considerably between authors, and ranges from $2 \%$ to $27.5 \%$. Values lower than $10 \%$ (namely $2 \%$ to $8.7 \%$ ) are mentioned (Becker, 1983; Busson, 1965; Murray et al., 2001; Nour et al., 1980; Wehmeyer, 1966), while higher values varying from 10 up to $27.5 \%$ are also reported (Lockett et al., 2000; Soloviev et al., 2004; Obizoba and Amaechi, 1993; Osman, 2004; Saka and Msonthi, 1994). The average of all reported values is $11.6 \%$. This average water content is a bit high for a powdery type of product such as baobab pulp and may negatively influence its shelf life.

\section{Carbohydrates}

Reported carbohydrate contents (Table 1) range from $46.6 \mathrm{~g} / 100 \mathrm{~g} \mathrm{dw}$ (Murray et al., 2001) to $88 \mathrm{~g} / 100 \mathrm{~g} \mathrm{dw}$ (Wehmeyer, 1966). The average of the reported values is 79.9 $\mathrm{g} / 100 \mathrm{~g} \mathrm{dw}$. Most authors determined carbohydrates by difference, so these values are not expected to be very accurate. However, Murray et al. (2001) determined different types of carbohydrates and only the fraction containing monosaccharides and disaccharides was calculated by difference. The presence of sugar was also mentioned by Soloviev et al. (2004), who found a total soluble sugar content of 7.2-11.2 g/100 g dw in baobab pulp, while Nour et al. (1980) reported $23.2 \%$ of total sugars and $19.9 \%$ of reducing sugars. According to Murray et al. (2001), simple sugars in baobab pulp account for about $35.6 \%$ of the total carbohydrate content. This explains the noticeable sweet taste of the pulp. However, the sweetness may vary for different types of pulp.

\section{Crude Proteins}

Generally, the reported crude protein content (Table 1) varies from $2.5 \mathrm{~g} / 100 \mathrm{~g} \mathrm{dw}$ (Lockett et al., 2000) to $3.6 \mathrm{~g} / 100 \mathrm{~g} \mathrm{dw}$ (Osman, 2004). However, Obizoba and Amaechi (1993) reported higher values of $15.3 \mathrm{~g} / 100 \mathrm{~g} \mathrm{dw}$ for protein in the pulp, using analytical methods similar to those applied by the other researchers. Most authors used Kjeldahl analysis with the conversion factor of 6.25 to determine the protein content of baobab pulp. Moreover, after amino acid analysis, Sena et al. (1998) mentioned a total protein content of $17 \mathrm{~g} / 100 \mathrm{~g} \mathrm{dw}$. The value mentioned by Sena et al. (1998) is comparable to the one of Obizoba and Amaechi (1993), despite the hydrolysis procedure before amino acid analysis.

\section{Crude Lipid}

The reported crude lipid contents (Table 1) of baobab pulp vary from $0.21 \mathrm{~g} / 100 \mathrm{~g} \mathrm{dw}$ (Nour et al., 1980) to $15.5 \mathrm{~g} / 100 \mathrm{~g}$ $\mathrm{dw}$ (Glew et al., 1997) with an average of $3.6 \mathrm{~g} / 100 \mathrm{~g} \mathrm{dw}$. The value reported by Glew et al. (1997) was obtained after fatty acids analysis (hydrolysis of sample before determination) and was quite similar to the one reported by Sena et al. (1998), who mentioned a total lipid content of $(12.7 \mathrm{~g} / 100 \mathrm{~g} \mathrm{dw})$. The highest values without fatty acid analyses, 4.3 and $4.1 \mathrm{~g} / 100$ $\mathrm{g} \mathrm{dw}$, respectively, were reported by Saka and Msonthi (1994) and Obizoba and Amaechi (1993), who however used (a) dilute acid hydrolysis and hexane extraction and (b) the method using the Soxtec system (extractable materials readily passed from the sample and dissolved in the organic solvent, similar to a tea bag in hot water for a duration of $1 \mathrm{~h}$ ), respectively. The latter method was also used by Lockett et al. (2000), who found a very low fat content of $0.41 \mathrm{~g} / 100 \mathrm{~g} \mathrm{dw}$. The Soxhlet and the gravimetric method were also mentioned, but all results were different; the great variation observed may have an origin other than the method used.

\section{Energy}

The energy value varies from $848.9 \mathrm{~kJ} / 100 \mathrm{~g} \mathrm{dw}$ (Murray et al., 2001) to $1494.9 \mathrm{~kJ} / 100 \mathrm{~g} \mathrm{dw}$ (Osman, 2004) (Table 1). The values reported averaged $1275 \mathrm{~kJ} / 100 \mathrm{~g}$. Note that the method for carbohydrate determination of Murray et al. (2001) was different from the generally used method of difference, and that this may have affected his result. Furthermore, the coefficients used by authors to compute the energy value are sometimes slightly different.

\section{Fibers}

Fiber contents are lower than $12.5 \%$ in most cases (Table 1), ranging generally from $6.0 \mathrm{~g} / 100 \mathrm{~g} \mathrm{dw}$ (Osman, 2004) to 12.5 $\mathrm{g} / 100 \mathrm{~g} \mathrm{dw}$ (Lockett et al., 2000). However, Murray et al. (2001) mentioned a high value of $45.1 \mathrm{~g} / 100 \mathrm{~g} \mathrm{dw}$, which is the maximum of the reported values. The average of the reported values is $13.7 \mathrm{~g} / 100 \mathrm{~g} \mathrm{dw}$. Murray et al. (2001) measured the fibers (after extraction of fat) by a gravimetric method, while the others used AOAC methods (Nour et al., 1980; Osman, 2004) or an acid and alkaline hydrolysis method (Saka and Msonthi, 1994).

\section{Ash}

The reported ash contents (Table 1) are from 4.1 (Busson, 1965) to $6.4 \mathrm{~g} / 100 \mathrm{~g} \mathrm{dw}$ (Lockett et al., 2000) with the exception of the very low value of $1.9 \mathrm{~g} / 100 \mathrm{~g} \mathrm{dw}$ reported by Obizoba and Amaechi (1993). The methods used by the authors vary considerably with respect to the time temperature combinations. 
Other Measurements

The pH of the pulp is about 3.3 (Nour et al., 1980). Soloviev et al. (2004) investigated total free acidity and their results show that baobab pulp contains 6.5-11.2 g equivalent malic acid per $100 \mathrm{~g} \mathrm{dw}$ (Table 1). These results indicate the acidic character of the pulp.

\section{Minerals}

The reported mineral contents of baobab pulp show a great variability between authors (Table 1 ). The values for magnesium vary from $100.5 \mathrm{mg} / 100 \mathrm{~g} \mathrm{dw}$ (Osman, 2004) to $300 \mathrm{mg} / 100 \mathrm{~g}$ (Sena et al., 1998) with an average value of $195.1 \mathrm{mg} / 100 \mathrm{~g}$. For potassium, the reported average value is $1793.8 \mathrm{mg} / 100 \mathrm{~g} \mathrm{dw}$ and it varies from $726 \mathrm{mg} / 100 \mathrm{~g}$ dw to $3272 \mathrm{mg} / 100 \mathrm{~g} \mathrm{dw}$ (Saka and Msonthi, 1994). Reported values for the calcium content are generally between $390 \mathrm{mg} / 100 \mathrm{~g} \mathrm{dw}$ (Prentice et al., 1993) and $700.9 \mathrm{mg} / 100 \mathrm{~g} \mathrm{dw}$ (Nour et al., 1980). However, a very low value of $3.0 \mathrm{mg} / 100 \mathrm{~g} \mathrm{dw}$ was reported by Obizoba and Amaechi (1993). The average of the reported values is $301.8 \mathrm{mg} / 100 \mathrm{~g}$ $\mathrm{dw}$. The reported sodium content varies from 0.8 (Sena et al., 1998) to $31.2 \mathrm{mg} / 100 \mathrm{~g} \mathrm{dw}$ (Osman, 2004) with an average of $14.8 \mathrm{mg} / 100 \mathrm{~g} \mathrm{dw}$. For copper, it goes from below the detection level (Glew et al., 1997) to $1.8 \mathrm{mg} / 100 \mathrm{~g} \mathrm{dw}$ (Osman, 2004); the average is $0.9 \mathrm{mg} / 100 \mathrm{~g} \mathrm{dw}$. The manganese content varies from below the detection level (Glew et al., 1997) to $1.0 \mathrm{mg} / 100$ $\mathrm{g} \mathrm{dw}$ (Sena et al., 1998). The average value is $0.7 \mathrm{mg} / 100 \mathrm{~g}$ $\mathrm{dw}$. For phosphorus, reported contents vary greatly from 0.04 $\mathrm{mg} / 100 \mathrm{~g} \mathrm{dw}$ (Obizoba and Amaechi, 1993) to $425 \mathrm{mg} / 100 \mathrm{~g}$ $\mathrm{dw}$ (Sena et al., 1998). The reported zinc content is generally low, ranging from 0.5 (Lockett et al., 2000) to $3.2 \mathrm{mg} / 100 \mathrm{~g} \mathrm{dw}$ (Sena et al., 1998) with an average of $1.7 \mathrm{mg} / 100 \mathrm{~g} \mathrm{dw}$. The iron content varies strongly from $1.1 \mathrm{mg} / 100 \mathrm{~g}$ (Arnold et al., 1995) to $10.4 \mathrm{mg} / 100 \mathrm{~g} \mathrm{dw}$ (Osman, 2004).

The methods used by the different researchers to determine minerals were generally atomic absorption methods. For instance, apart from P for which Lockett et al. (2000) used the Technicon Auto-analyser methodology, they used a flame atomic absorption spectroscopy method for the other minerals. Sena et al. (1998) used the same method as Glew et al. (1997), namely the inductively coupled argon plasma atomic emission spectroscopy. Saka and Msonthi (1994) estimated P colorimetrically by the ammonium molybdate method, determined $\mathrm{Ca}, \mathrm{Mg}$, and Fe by the atomic absorption technique using a Perkin-Elmer 500 spectrophotometer, and analyzed $\mathrm{K}$ and Na using a corning 400 flame photometer. Obizoba and Amaechi (1993) used the polarized Zeeman atomic absorption spectrophotometry. In contrast to the others, Nour et al. (1980), who also used a molybdenum colorimetric method to determine $\mathrm{P}$, determined the other minerals using a thiocyanate method for $\mathrm{Fe}$, oxalate precipitation for $\mathrm{Ca}$, and estimated $\mathrm{Mg}$. The large variation in the reported data may be due to the methods used, but may also have other origins, that will be discussed further.

\section{Vitamins}

Authors have investigated mainly vitamin C. There is a great variability and the average of the reported values is $283 \mathrm{mg} / 100$ g. Scheuring et al. (1999) found that there is a remarkable tree-totree variability in the vitamin $\mathrm{C}$ content of the fruit pulp, ranging from 150 to $500 \mathrm{mg} / 100 \mathrm{~g}$, which constitutes actually the minimum and the maximum of the reported values. The figures were found to be quite stable from one year to the next (Scheuring et al., 1999). Possible explanations given for this variability are soil type, genetic make-up, and morphotypes. Sena et al. (1998) investigated the carotenoid content of the pulp and found that it contains $1.53 \mu \mathrm{g} / \mathrm{g} \mathrm{dw}$ of lutein, $0.17 \mu \mathrm{g} / \mathrm{g} \mathrm{dw}$ of $\alpha$-carotene and $0.17 \mu \mathrm{g} / \mathrm{g} \mathrm{dw}$ of $\beta$-carotene.

The investigation of group B vitamins in the pulp also showed large variations. Data ranged from 1.8 to $2.7 \mathrm{mg} / 100$ for vitamin B3, niacin, as reported by Santos Oliveira (1975) and Arnold et al. (1995), respectively. The riboflavin content ranges from $0.07 \mathrm{mg} / 100 \mathrm{~g}$ (Becker, 1983) to $0.14 \mathrm{mg} / 100 \mathrm{~g}$ (Arnold et al., 1995). The methods used to determine each vitamin seldom are described, which makes it hard to evaluate these figures critically.

\section{Amino Acids}

There is a large variability in the reported amino acid contents of baobab fruit pulp (Table 1), despite the fact that the authors (Sena et al., 1998; Glew et al., 1997; Osman, 2004) used similar methods for determination. They all hydrolyzed the samples in the described procedures. The results show that most essential amino acids are present. The highest average contents were found for tyrosine $(8.5 \mathrm{~g} / 100 \mathrm{~g}$ protein), glutamic acid $(8.4 \mathrm{~g} / 100 \mathrm{~g}$ protein), aspartic acid $(7.5 \mathrm{~g} / 100 \mathrm{~g}$ protein), arginine $(6.8 \mathrm{~g} / 100 \mathrm{~g}$ proteins), and glycine $(6.2 \mathrm{~g} / 100 \mathrm{~g}$ protein). The lowest values were found for the sulphur containing amino acids, namely cystein $(1.3 \mathrm{~g} / 100 \mathrm{~g}$ protein) and methionine (1.9 $\mathrm{g} / 100 \mathrm{~g}$ protein).

\section{Fatty Acids}

Most fatty acids in the pulp do not reach detectable levels. Similarly to the amino acids, the variability in the reported values is high (Table 1), despite the use of identical methods by the researchers. The content of oleic acid is the highest reported value among all fatty acids $(25 \mathrm{mg} / \mathrm{g} \mathrm{dw})$.

\section{Antinutrients}

The baobab fruit pulp, as other plant fruits, contains naturally occurring antinutritional substances. Tannin content of the pulp varies between $0.0051 \%$ and $0.0062 \%$ (Ghani and Agbejule, 1986). This level is too low to cause any harmful effects on consumers (Ghani and Agbejule, 1986). Other harmful components 
estimated by Ghani and Agbejule (1986) include: hydrocyanic acid $(\mathrm{HCN})(0.0049 \% \mathrm{dw})$ and total oxalate $(0.0044 \% \mathrm{dw})$. However, the detected levels were not alarming (Ghani and Agbejule, 1986).

\section{THE WHOLE SEEDS}

\section{Macronutrients}

Two authors reported the water content of the whole seeds to be $6.1 \%$ (Proll et al., 1998) and 8.2\% (Lockett et al., 2000). They also reported an energy value of $1935 \mathrm{~kJ} / 100 \mathrm{~g} \mathrm{dw}$ and 1589.8 $\mathrm{kJ} / 100 \mathrm{~g} \mathrm{dw}$, respectively. The average carbohydrate content is $31.7 \mathrm{~g} / 100 \mathrm{~g} \mathrm{dw}$, with values ranging from $5.2 \mathrm{~g} / 100 \mathrm{~g} \mathrm{dw}$ (Arnold et al., 1995) to $56.8 \mathrm{~g} / 100 \mathrm{~g} \mathrm{dw}$ (Proll et al., 1998). The crude lipid content ranges from $9 \mathrm{~g} / 100 \mathrm{~g} \mathrm{dw}$ (Glew et al., 1997) to $33.3 \mathrm{~g} / 100 \mathrm{~g} \mathrm{dw}$ (Arnold et al., 1995). Ezeagu et al. (1998) mentioned a fat content of $14.8 \%$ on fresh weight basis, which is lower than that of some soybean varieties (Glycine max TGX 1660-15F, TGX 1740-6F, TGX 1740-2F, TGX 1649-11F, TGX $1681-3 \mathrm{~F}$ ), of which the fat content varied from 18.6 to $22.2 \%$ on fresh weight basis. The fiber content is reported to vary from $16.9 \mathrm{~g} / 100 \mathrm{~g} \mathrm{dw}$ (Osman, 2004) to $49.7 \mathrm{~g} / 100 \mathrm{~g} \mathrm{dw}$ (Lockett et al., 2000), while the ash content has an average value of 5.3 $\mathrm{g} / 100 \mathrm{~g} \mathrm{dw}$. The crude protein content varies from $14.4 \mathrm{~g} / 100 \mathrm{~g}$ dw (Proll et al., 1998) to $36.7 \mathrm{~g} / 100 \mathrm{~g} \mathrm{dw}$ (Arnold et al., 1995) with an average value of $21.4 \mathrm{~g} / 100 \mathrm{~g} \mathrm{dw}$ (Table 1). The timetemperature combination for the moisture and ash measurements differs from one author to another. The crude protein contents are mostly measured according to Kjeldahl methods using 6.25 as conversion factor, except for a determination after measurement of amino acids by Glew et al. (1997).

\section{Minerals}

The mineral levels in whole seeds are presented in Table 1. The magnesium content of the whole seeds is reported to vary from $282.2 \mathrm{mg} / 100 \mathrm{~g} \mathrm{dw}$ (Osman, 2004) to $696.3 \mathrm{mg} / 100 \mathrm{~g} \mathrm{dw}$ (Arnold et al., 1995) with an average value of $402 \mathrm{mg} / 100 \mathrm{~g}$ $\mathrm{dw}$. This is much higher than reported for the kernels. The same was observed for potassium and calcium, that range from 428.5 $\mathrm{mg} / 100 \mathrm{~g} \mathrm{dw}$ (Osman, 2004) to $1387.2 \mathrm{mg} / 100 \mathrm{~g} \mathrm{dw}$ (Arnold et al., 1995) with an average of $908 \mathrm{mg} / 100 \mathrm{~g} \mathrm{dw}$; and from 29.6 $\mathrm{mg} / 100 \mathrm{~g} \mathrm{dw}$ (Osman, 2004) to $395 \mathrm{mg} / 100 \mathrm{~g} \mathrm{dw}$ (Glew et al., 1997) with an average of $252 \mathrm{mg} / 100 \mathrm{~g} \mathrm{dw}$, respectively. The sodium content varies from $1.9 \mathrm{mg} / 100 \mathrm{~g} \mathrm{dw}$ (Glew et al., 1997) to $2.7 \mathrm{mg} / 100 \mathrm{~g} \mathrm{dw}$ (Arnold et al., 1995) and the average is 2.3 $\mathrm{mg} / 100 \mathrm{~g} \mathrm{dw}$. The average copper content is $2.3 \mathrm{mg} / 100 \mathrm{~g} \mathrm{dw}$ and values range from $1.3 \mathrm{mg} / 100 \mathrm{~g} \mathrm{dw}$ (Lockett et al., 2000) to $3 \mathrm{mg} / 100 \mathrm{~g} \mathrm{dw}$ (Arnold et al., 1995). The average manganese content $1.1 \mathrm{mg} / 100 \mathrm{~g} \mathrm{dw}$. The average zinc content is $5.0 \mathrm{mg} / 100$ $\mathrm{g} \mathrm{dw}$ and values range from $2.6 \mathrm{mg} / 100 \mathrm{~g} \mathrm{dw}$ (Glew et al., 1997) to $7.3 \mathrm{mg} / 100 \mathrm{~g} \mathrm{dw}$ (Arnold et al., 1995). The iron content varies from $1.8 \mathrm{mg} / 100 \mathrm{~g} \mathrm{dw}$ (Glew et al., 1997) to $7.1 \mathrm{mg} / 100 \mathrm{~g} \mathrm{dw}$ (Arnold et al., 1995) with an average value of $5.1 \mathrm{mg} / 100 \mathrm{~g}$ dw. The phosphorus contents vary greatly from $5.6 \mathrm{mg} / 100 \mathrm{~g}$ $\mathrm{dw}$ (Arnold et al., 1995) to $738.3 \mathrm{mg} / 100 \mathrm{~g} \mathrm{dw}$ (Lockett et al., 2000) (Table 1) with an average value of $453 \mathrm{mg} / 100 \mathrm{~g} \mathrm{dw}$. A comparison of these data with those of the kernels (described below) shows how rich the coat is in several minerals, namely $\mathrm{Ca}, \mathrm{P}$, and $\mathrm{Mg}$.

\section{Vitamins}

Not much has been reported on the vitamin content of the whole seeds. However, Arnold et al. (1995) found that the seeds contain $0.25 \mathrm{mg} / 100 \mathrm{~g} \mathrm{dw}, 0.14 \mathrm{mg} / 100 \mathrm{~g} \mathrm{dw}$ and $1.0 \mathrm{mg} / 100 \mathrm{~g}$ $\mathrm{dw}$ of thiamine, riboflavin, and niacin, respectively. The method used for the determinations was not specified.

\section{Amino Acids}

The levels of amino acids in whole seeds are presented in Table 1. Considering the average value, whole seeds are very rich in glutamic acid (35.9 g/100 g protein), aspartic acid (16.9 g/100 g protein), arginine (11.6 g/100 g protein), leucine (10.6 g/100 g protein), proline (9.1 g/100 g protein), glycine ( $8.8 \mathrm{~g} / 100 \mathrm{~g}$ protein), serine $(8.3 \mathrm{~g} / 100 \mathrm{~g}$ protein $)$, phenylalanine ( $7.2 \mathrm{~g} / 100 \mathrm{~g}$ protein), and lysine $(6.9 \mathrm{~g} / 100 \mathrm{~g}$ protein). The lowest average value was found for methionine $(1.9 \mathrm{~g} / 100 \mathrm{~g}$ protein).

\section{Fatty Acids}

The fatty acid content of the whole seeds is presented in Table 4. The presence of a relatively high quantity of oleic acid can be observed (Glew et al., 1997).

\section{Antinutritional Factors}

Baobab seeds contain some antinutritional factors that can be removed or inactivated by different processing methods. Osman (2004) investigated the antinutritional factors in baobab seeds and found that they contain a Trypsin Inhibitor Activity of 5.7 TIU/mg sample, $73 \mathrm{mg} / 100 \mathrm{~g}$ of phytic acid and $23 \%$ catechin equivalent of tannin. Igboeli et al. (1997) investigated the effects of some processing techniques on the antinutrient composition of baobab seeds and found that cold water, hot water, hot alkali, and acid treatments reduced the tannic acid concentration in baobab seeds significantly. However, dehulling did not lead to significant decreases (from $400 \mu \mathrm{g}$ tannic acid/g in the whole seeds to $390 \mu \mathrm{g}$ tannic acid/g in the dehulled seeds). The activity of amylase inhibitors in the seeds was reduced significantly by dehulling (from 35 to $10 \mu \mathrm{g} / 100 \mathrm{~g}$ ), cold water, and hot alkali treatments. Moreover, fermentation reduced the antinutrient 
Table 4 Reported fatty acid content of baobab whole seeds

\begin{tabular}{|c|c|c|c|c|c|c|c|c|c|c|c|c|c|}
\hline Authors & $\begin{array}{c}\text { C14:0 } \\
\text { mystiric }\end{array}$ & $\begin{array}{l}\text { C16:0 } \\
\text { palmitic }\end{array}$ & $\begin{array}{c}\text { C16:1 } \\
\text { palmitoleic }\end{array}$ & $\begin{array}{l}\text { C16:2 } \\
\text { hexade } \\
\text { cadienic }\end{array}$ & C17:1 & $\begin{array}{l}\text { C18:0 } \\
\text { stearic }\end{array}$ & $\begin{array}{l}\text { C18:1 } \\
\text { oleic }\end{array}$ & $\begin{array}{c}\mathrm{C} 18: 2 \\
\text { linoleic }\end{array}$ & $\begin{array}{c}\mathrm{C} 18: 3 \\
\text { linolenic }\end{array}$ & $\begin{array}{c}\text { C20:0 } \\
\text { arachidic }\end{array}$ & $\begin{array}{l}\text { C20:1 } \\
\text { gadoleic }\end{array}$ & $\begin{array}{l}\text { C22:0 } \\
\text { behenic }\end{array}$ & $\begin{array}{c}\mathrm{C} 24: 0 \\
\text { lignoceric }\end{array}$ \\
\hline $\begin{array}{l}\text { Glew et al., } 1997 \\
\text { (g fatty acid/100 g } \\
\text { dw material)* }\end{array}$ & & 0.14 & 0.002 & & & 0.016 & 0.21 & 0.13 & 0.002 & & & & \\
\hline
\end{tabular}

*Converted values

contents (phytate and tannins) of baobab seeds (Nnam and Obiakor, 2003).

\section{THE KERNELS}

The cream-colored kernels are obtained by removing the shell from the whole seeds. Traditionally, the whole seeds are soaked and boiled for 2-3 hours. Afterwards, the seeds are individually and manually dehulled. Next, the kernels are dried. This operation is one of the most difficult ones in the traditional processing of baobab parts.

\section{Macronutrients}

As presented in Table 1, the average reported water content is $7.2 \%$. It ranges from 6.4\% (Igboeli et al., 1997) to $8.1 \%$ (Obizoba and Amaechi, 1993). The energy value mentioned by Igboeli et al. (1997) is $1965.5 \mathrm{~kJ} / 100 \mathrm{~g} \mathrm{dw}$. The carbohydrate content ranges from $22.1 \mathrm{~g} / 100 \mathrm{~g} \mathrm{dw}$ (Ajayi et al., 2003) to $48.1 \mathrm{~g} / 100$ $\mathrm{g} \mathrm{dw}$ (Nnam and Obiakor, 2003). The average of the reported crude protein contents is $24.7 \mathrm{~g} / 100 \mathrm{~g} \mathrm{dw}$, ranging from $14 \mathrm{~g} / 100$ $\mathrm{g} \mathrm{dw}$ (Nnam and Obiakor, 2003) to $32.7 \mathrm{~g} / 100 \mathrm{~g} \mathrm{dw}$ (Obizoba and Amaechi, 1993). The crude lipid content has an average of $27.8 \mathrm{~g} / 100 \mathrm{~g} \mathrm{dw}$. A fiber content of $21.2 \mathrm{~g} / 100 \mathrm{~g} \mathrm{dw}$ is mentioned (Ajayi et al., 2003) and the average ash content is $6.5 \mathrm{~g} / 100 \mathrm{~g}$ $\mathrm{dw}$. The kernels appear to be a good source of protein and energy and may be an interesting ingredient for designing formulated infant foods.

\section{Minerals}

The kernels were investigated for their mineral content by several authors (Table 1). They were reported to have an average potassium content of $6.6 \mathrm{mg} / 100 \mathrm{~g} \mathrm{dw}$, with a minimum of $0.6 \mathrm{mg} / 100 \mathrm{~g} \mathrm{dw}$ (Nnam and Obiakor, 2003) and a maximum of $17.3 \mathrm{mg} / 100 \mathrm{~g} \mathrm{dw}$ (Ajayi et al., 2003). The magnesium content ranges from $0.2 \mathrm{mg} / 100 \mathrm{~g} \mathrm{dw}$ (Odetokun, 1996) to $1.1 \mathrm{mg} / 100$ $\mathrm{g} \mathrm{dw}$ (Ajayi et al., 2003) with an average of $0.7 \mathrm{mg} / 100 \mathrm{~g} \mathrm{dw}$. The calcium content ranges from $0.4 \mathrm{mg} / 100 \mathrm{~g} \mathrm{dw}$ (Ajayi et al.,
2003) to $3.8 \mathrm{mg} / 100 \mathrm{~g} \mathrm{dw}$ (Obizoba and Amaechi, 1993); the sodium content from $0.2 \mathrm{mg} / 100 \mathrm{~g} \mathrm{dw}$ (Ajayi et al., 2003) to $1.6 \mathrm{mg} / 100 \mathrm{~g} \mathrm{dw}$ (Odetokun, 1996); copper from $0.02 \mathrm{mg} / 100 \mathrm{~g}$ $\mathrm{dw}$ (Nnam and Obiakor, 2003) to $5.4 \mathrm{mg} / 100 \mathrm{~g} \mathrm{dw}$ (Odetokun, 1996); manganese from $0.2 \mathrm{mg} / 100 \mathrm{~g} \mathrm{dw}$ (Ajayi et al., 2003) to $2.8 \mathrm{mg} / 100 \mathrm{~g} \mathrm{dw}$ (Odetokun, 1996); zinc from $0.1 \mathrm{mg} / 100 \mathrm{~g} \mathrm{dw}$ (Ajayi et al., 2003) to $3.6 \mathrm{mg} / 100 \mathrm{~g} \mathrm{dw}$ (Obizoba and Amaechi, 1993); and iron from $0.6 \mathrm{mg} / 100 \mathrm{~g} \mathrm{dw}$ (Nnam and Obiakor, 2003) to $2.4 \mathrm{mg} / 100 \mathrm{~g} \mathrm{dw}$ (Obizoba and Amaechi, 1993). The phosphorus content is reported to vary greatly from $0.4 \mathrm{mg} / 100 \mathrm{~g}$ dw (Obizoba and Amaechi, 1993) to $326.3 \mathrm{mg} / 100 \mathrm{~g} \mathrm{dw}$ (Nnam and Obiakor, 2003).

For the determination of minerals, Ajayi et al. (2003) used the method described by Idouraine et al. (1996), while Nnam and Obiakor (2003) used the atomic absorption spectrophotometer. Odetokun (1996) determined $\mathrm{Na}$ and $\mathrm{K}$ by a flame photometer and the other minerals by atomic absorption spectrophotometry. Obizoba and Amaechi (1993) determined Ca, Zn, Cu, P, and Fe by polarized Zeeman atomic absorption spectrophotometry.

The huge differences found may be due to the use of different methods, but may also have other causes.

\section{Vitamins}

No published reports on the vitamin content of the kernels were encountered.

\section{Amino Acids}

Amino acid contents have been investigated in the whole seeds, but not specifically for the kernels.

\section{Fatty Acids}

The data reported by Ajayi et al. (2003) and Odetokun (1996) show that the kernels are rich in oleic acid (26.1 to 58.2\%) and linoleic acid (23.3\% to $39.4 \%$ ) as indicated in Table 5. Moreover, Ajayi et al. (2003) mention $2.1 \%$ cerotic acid and $3.2 \%$ of other (unspecified) acids; in total, the seed oil contains $26.9 \%$ of saturated fatty acids and $73.1 \%$ of unsaturated fatty acids. It is 
Table 5 Fatty acids content of the baobab kernels.

\begin{tabular}{|c|c|c|c|c|c|c|c|c|c|c|c|c|}
\hline Authors & $\begin{array}{l}\mathrm{C} 12: 0 \\
\text { lauric }\end{array}$ & $\begin{array}{l}\text { C14:0 } \\
\text { mystiric }\end{array}$ & $\begin{array}{l}\text { C16:0 } \\
\text { palmitic }\end{array}$ & $\begin{array}{c}\mathrm{C} 16: 1 \\
\text { palmitoleic }\end{array}$ & $\begin{array}{l}\text { C18:0 } \\
\text { stearic }\end{array}$ & $\begin{array}{l}\text { C18:1 } \\
\text { oleic }\end{array}$ & $\begin{array}{l}\text { C18:2 } \\
\text { linoleic }\end{array}$ & $\begin{array}{c}\mathrm{C} 18: 3 \\
\text { linolenic }\end{array}$ & $\begin{array}{c}\text { C20:0 } \\
\text { arachidic }\end{array}$ & $\begin{array}{c}\text { C20:1 } \\
\text { gadoleic }\end{array}$ & $\begin{array}{l}\text { C22:0 } \\
\text { behenic }\end{array}$ & $\begin{array}{c}\mathrm{C} 24: 0 \\
\text { lignoceric }\end{array}$ \\
\hline $\begin{array}{l}\text { Ajayi et al., } 2003 \\
\text { (\% of total fatty } \\
\text { acid) }\end{array}$ & & & 4.43 & & 3.98 & 26.07 & 39.4 & & 2.26 & 4.01 & 3.46 & 10.7 \\
\hline $\begin{array}{l}\text { Odetokun, } 1996 \\
\text { (\% of total fatty } \\
\text { acid) }\end{array}$ & 0.34 & 1.46 & 2.22 & 1.65 & & 58.71 & 23.3 & 8.2 & & 3.64 & & \\
\hline
\end{tabular}

recognized that an increased dietary intake of saturated fat and (to a lesser extent cholesterol), raises plasma/serum total and low-density lipoprotein (5LDL)- cholesterol, and of polyunsaturated fatty acids (PUFA) decreases these levels (Li and Sinclair, 2002). Because of its high proportion of unsaturated fatty acid, baobab kernels may have a positive effect on human health.

\section{SOME CHARACTERISTICS OF SEED OIL}

\section{Sterols}

The Baobab Fruit Company (www.baobabfruitco.com) collected data from literature and presented some results on sterols. Some data are also provided by Gaydou et al. (1979). Table 6 shows that the seed oil contains $75-81 \%$ of $\beta$-sitosterol followed by campesterol (6-6.3\%). $\beta$-sitosterol, campesterol, and stigmasterol are the main sterols in plants and constitute bioactive compounds that can decrease the plasma/serum levels of lipids and lipoprotein lipids (Li and Sinclair, 2002).

\section{Fatty Acids}

According to Osman (2004), baobab seed oil is an excellent source of mono- and polyunsaturated fatty acids (Table 7a). The oil is composed of approximately $31.7 \%$ saturated fatty acids, $37 \%$ monounsaturated fatty acids, and $31.7 \%$ polyunsaturated fatty acids. The major fatty acid is oleic acid, which comprises $35.8 \%$, followed by linoleic (30.7\%) and palmitic (24.2\%) acids. Reported by Gaydou et al. (1979), saturated fatty acids accounted for $34.6 \%$ of the fatty acids in baobab

Table 6 Sterols in baobab seeds oil

\begin{tabular}{lcc}
\hline $\begin{array}{l}\text { Sterol } \\
\text { compostion }\end{array}$ & $\begin{array}{c}\text { Sidibe and Williams, } 2002 \\
(\% \text { of total sterol })\end{array}$ & $\begin{array}{c}\text { Gaydou et al., 1979 } \\
(\% \text { of total sterol })\end{array}$ \\
\hline Cholesterol & 2 & 1.9 \\
Campesterol & 6 & 6.3 \\
Stigmasterol & $1-2$ & 81 \\
$\beta$-Sitosterol & 75 & 3.4 \\
$\Delta$ 5-Avenasterol & 0.5 & 4.8 \\
$\Delta$ 7-Stigmasterol & 0.6 & 0.6 \\
$\Delta 7$-Avenasterol & 12 & 2.0 \\
Stigmasterol & & \\
\hline
\end{tabular}

seed oil. However, the genus Adansonia has been reported to contain a particularly large proportion of cyclopropenoic fatty acids in their seed oil. Baobab oil from Adansonia sp. was reported to contain $6.3 \%$ malvalic acid, and $6.5 \%$ sterculic acid (12.8\% total cyclopropenes). More specifically, Adansonia digitata seed oil contains 3.1-6.2\% malvalic acid; $1.0-1.9 \%$ sterculic acid and then $4.1-8.1 \%$ total cyclopropenes (Table 7) (Aitzetmüller, 1996). Cyclopropenoic fatty acids are toxic with a higher toxicity with sterculic acid compared to malvalic acid (Andrianaivo-Rafehivola et al., 1994a). Biological effects are growth restriction and dysfunction of genital systems in chicken, rats, and mice as well as an induction of liver cancer in hardhead (Oncorhynchus mykiss), when cyclopropenes are combined with aflatoxins (Andrianaivo-Rafehivola et al., 1994a). Cyclopropenoic fatty acids, when present in an edible oil, have to be removed during refining to render the oil edible; AndrianaivoRafehivola et al. (1994b) showed that heating at $180^{\circ} \mathrm{C}$ or $220^{\circ} \mathrm{C}$ reduces the cyclopropenoic fatty acid content of oil by $60 \%$ or $96 \%$, respectively. This implies that locally produced baobab seed oil should be refined before consumption.

\section{Indices}

The specific gravity, the refractive index at different temperatures, as well as the iodine value, saponification value, and other indices are presented in Table $7 \mathrm{~b}$. The reported values for the specific gravity do not vary much and have a value of approximately 0.9 at $25^{\circ} \mathrm{C}$. The refractive index is in the range of 1.5 . The iodine value varies from 49.5 (Ajayi et al., 2003) to 88 (Osman, 2004).

\section{DISCUSSION AND CONCLUSION}

\section{Variation in Reported Data}

This review shows that the reported values of nutrient contents of baobab parts vary greatly. The causes of these variations are not well known but several assumptions can be made. This variation may be due to the quality of the sample (mixture of samples, or samples obtained from markets or samples from individual trees), the provenance of the samples, the age of the sample, the treatment before analysis, the analytical methods 


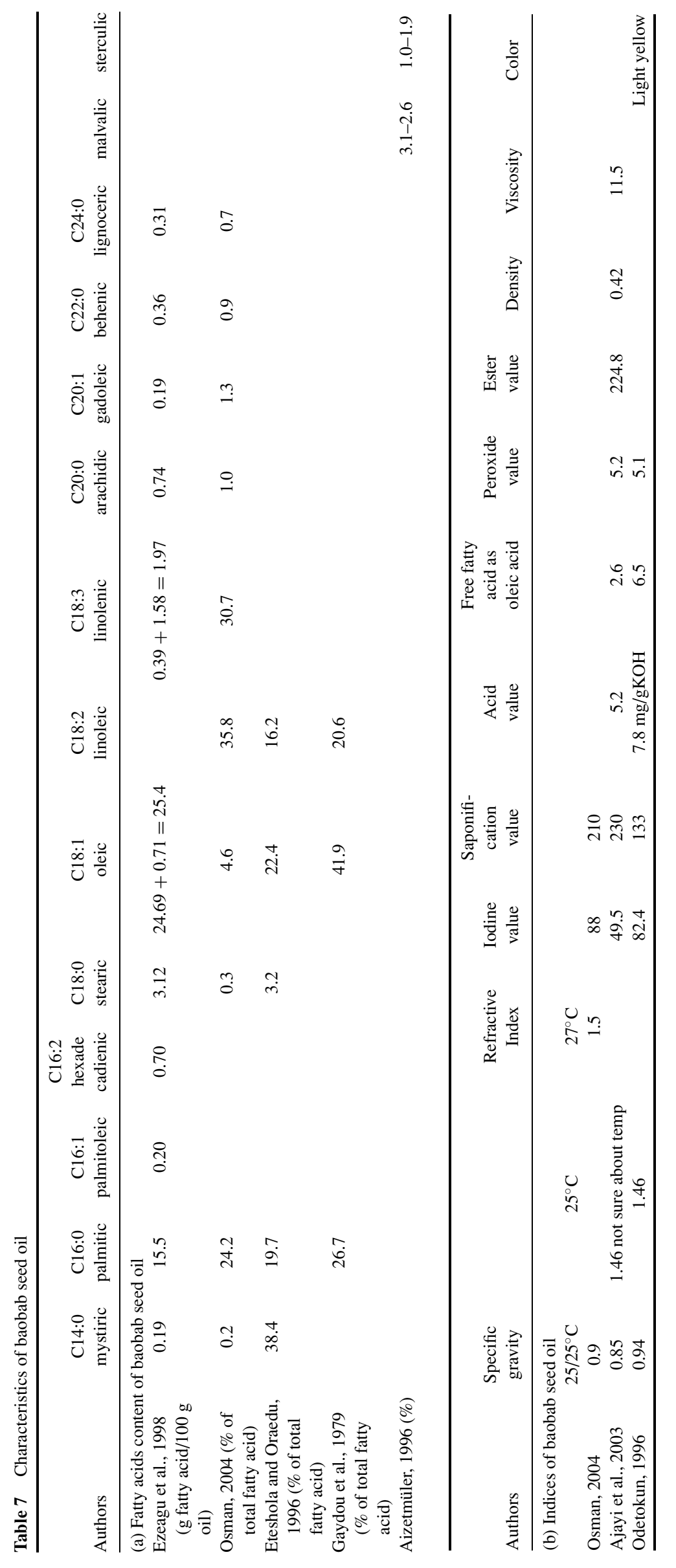


used, the storage conditions, the processing method, a probable genetic variation, and the soil structure and its chemical composition.

The composition of a food can be influenced significantly by the environment such as soil type, fertilizer, water or sunlight intensity. For instance, Maranz et al. (2004) investigated the chemical composition of 42 populations of the Shea butter or Karité tree (Vitellaria paradoxa) in 11 countries and found very high variability in all measured parameters, both within and between populations. The mineral content of the soils needs to be considered when dealing with the mineral content of the plant. The variation found in the reported data on the composition of baobab parts may be partially explained by the fact that baobab trees grow on a wide range of soils, ranging from deep, consolidate sands to well-drained clayey soils and coal limestone.

If the biochemical composition of a food depends on its genetic make-up, variability can also be attributed to genetic factors. In Benin, for instance, a genetic variability has been identified for baobab populations by Assogbadjo et al. (2006) but the relation with the composition of the food products from these baobab populations is not yet known. However, in Mali, measurements of bulked fruit samples from many baobab trees consistently resulted in vitamin $C$ values of around $220 \mathrm{mg} / 100$ g. It was only when researchers measured bulked fruit from individual trees that a threefold range of values from 150 to 500 $\mathrm{mg} / 100 \mathrm{~g}$ vitamin $\mathrm{C}$ was discovered (Anonymous, 1998). According to Diop et al. (2005), variations are obviously also due to the variability of the raw material (habitat, maturity, and storage conditions of samples). Indeed, the investigated literature shows that the analyzed samples were selected and handled differently. For instance, some researchers purchased their baobab material from local markets, e.g. Nnam and Obiakor (2003), Lockett et al. (2000), Obizoba and Amaechi (1993) and Yazzie et al. (1994). In Mali for instance, it has been noticed that $\beta$-carotene and vitamin $C$ levels were much lower in market samples than in any sample that was gathered directly from trees; market samples are frequently adulterated with worthless material such as cereal stalk pulp (Scheuring et al., 1999; Anonymous, 1998). However, some authors like Soloviev et al. (2004) and Scheuring et al. (1999), collected their material in the field. In this case, the degree of maturity of the biological material matters, and is linked to the method of harvesting; fruit harvested by knocking on branches or cutting from the tree will invariably include unripe fruit. Such unripe fruits do not show any ascorbic acid content until the moisture of baobab pulp decreases below $75 \%$ (Carr, 1958). Moreover, the storage conditions before analysis differ; while Osman (2004) stored his samples at $-20^{\circ} \mathrm{C}$ in tight plastic jars before analysis, Nnam and Obiakor (2003) boiled and dried the seeds before keeping them in Kilner jars for analysis. The form in which the product is analysed also matters (Joyanes and Lema, 2006). In the present literature review, it was observed that leaves, for example, were analyzed after drying but that the method of drying (sun or shade for instance) was seldom specified. It was found in Mali that baobab leaves dried in the shade may contain twice as much Retinol Equivalent (pro-vitamin A) than sun-dried leaves, even though sun drying is the common local practice (Anonymous, 1998). The age of the samples may also induce some variability in their composition. In the case of vitamin $\mathrm{C}$, for instance, pulp samples stored in clear glass bottles and partly exposed to sunlight showed 6.4 to $14.1 \%$ loss of ascorbic acid. Samples exposed to a longer storage (14 months), direct sunlight and exposure to air showed losses of up to $45.5 \%$ of ascorbic acid (Carr, 1958). In addition, an entire leaf consists of a petiole and a number of leaflets and it is often not specified whether the analyses concern leaflets or entire leaves.

Apart from the variability in the material, the analytical methods (sampling plans, sampling methods, analytical methods, analytical quality control) and inherent variability may also be a cause of variability. Considering seed oil, for instance, the method of extraction of the oil may affect its composition.

Moreover, some of the micronutrients, such as vitamins and minerals, are biologically active. They can interact with other nutrients and change in their bioavailability; because they are biological material, there is a natural variation in their composition (Joyanes and Lema, 2006).

Our review shows that more attention must be paid to all stages involved in performing analyses before we can make reliable statements on the variation in composition of baobab food products.

\section{Contribution to Recommended Daily Intake}

Note: in the following calculation, digestibility and bioavailability could not be taken into account, because of lack of data. Therefore, the values given should be seen as maximum values; in reality they are probably lower.

\section{Leaves}

Without considering the conversion factor or the effect of processing, such as cooking, the consumption of $20 \mathrm{~g}$ of dry leaf material would cover 10 to $16 \%$ of the protein RDI for children (4-8 y). Considering the highest reported values, $20 \mathrm{~g}$ would be enough to cover $89 \%$ of the zinc RDI and $66 \%$ of the calcium RDI for children (Table 8). Similarly, consumption of $20 \mathrm{~g}$ will cover $53 \%$ of the calcium RDI and $41 \%$ of the zinc RDI for pregnant women when considering the highest reported values (Table 9). The large gap between the lowest and highest reported values of iron makes it difficult to make a reliable prediction for this mineral. A bioavailability study is necessary to obtain a reliable assessment. Finally, the introduction of baobab nurseries for leaf production is becoming increasingly popular. The nutritional composition and digestibility of these leaves also require investigation.

\section{Pulp}

Irrespective of the variation in the reported values, the data reveal the high vitamin $\mathrm{C}$ content of the pulp. A comparison 


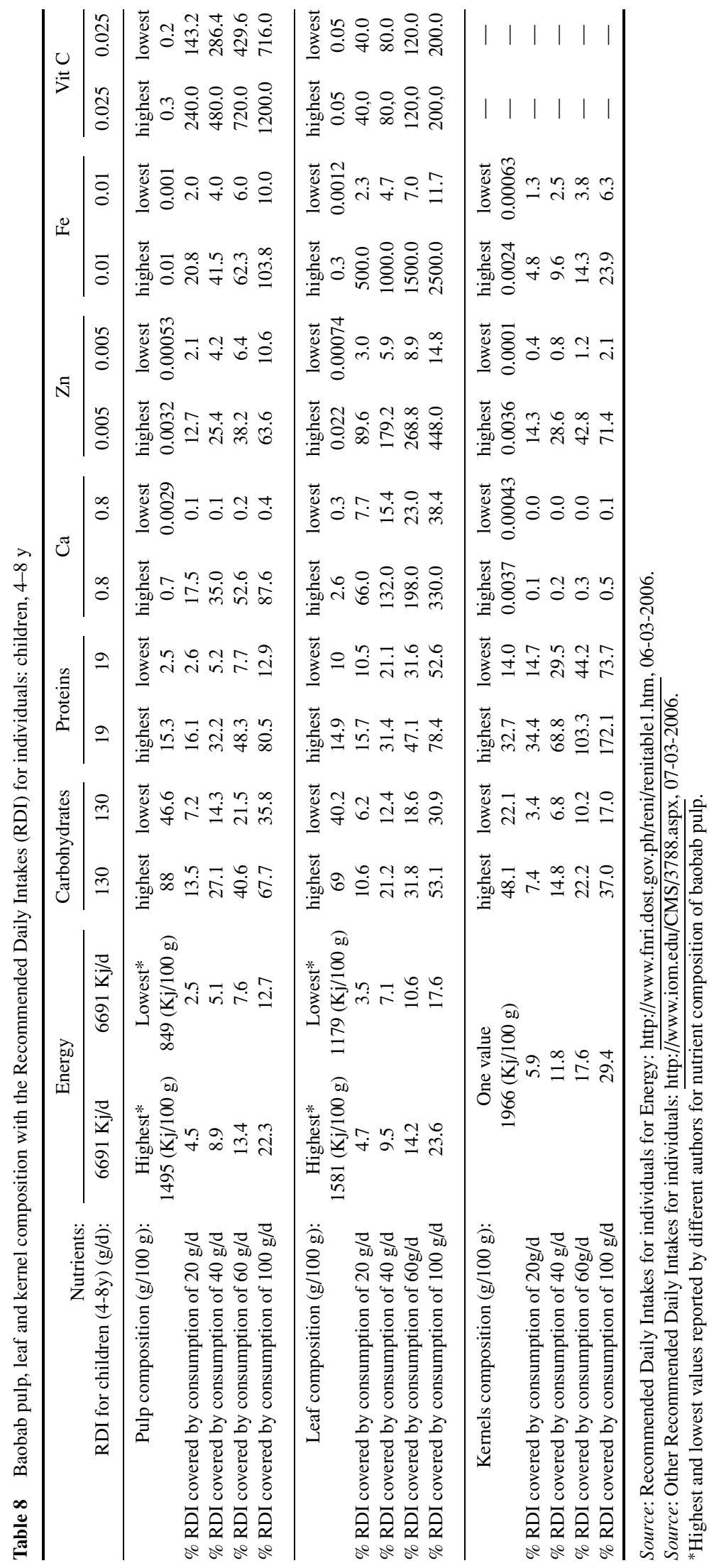




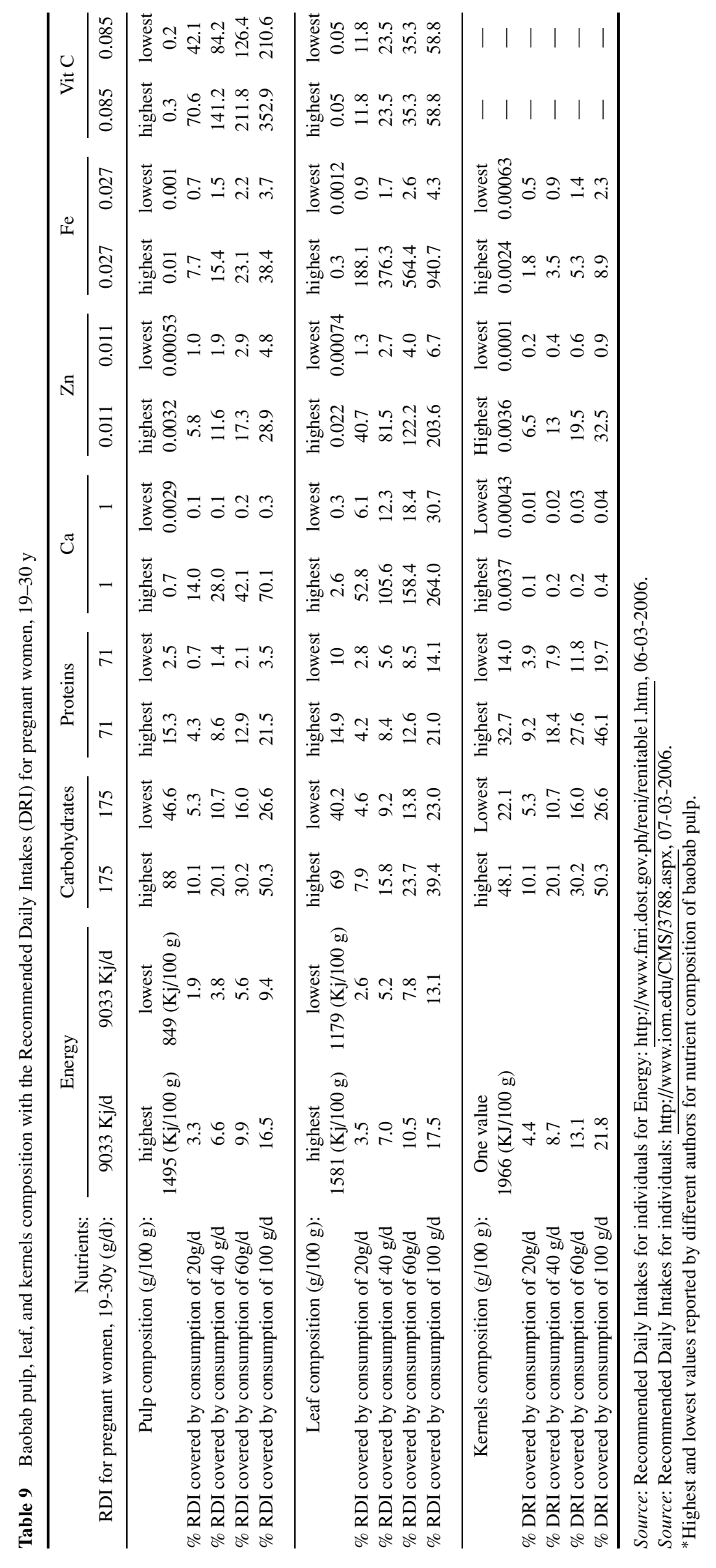


with the Recommended Daily Intake (RDI) for children (4-8 y) and for pregnant women (19-30 y) is presented in Tables 8 and 9 , respectively.

A consumption of $20 \mathrm{~g}$ of pulp by a child ( $4-8 \mathrm{y}$ ) will cover $143 \%$ of the RDI, considering the lowest reported vitamin C content by the authors. If the highest reported vitamin $\mathrm{C}$ content is considered, the coverage will even be $240 \%$ for the same quantity. In other words, $13.9 \mathrm{~g}$ of pulp with the lowest reported vitamin $\mathrm{C}$ content and $8.3 \mathrm{~g}$ of pulp with the highest reported vitamin $\mathrm{C}$ content is enough to cover the RDI of such a child. Moreover, according to Carr (1955), the bulk of the vitamin C in baobab pulp is present in the reduced form $(307 \mathrm{mg} / 100 \mathrm{~g}$ of reduced form out of $328 \mathrm{mg} / 100 \mathrm{~g}$ vitamin C). As the major metabolites of ascorbic acid in the human body are dehydroascorbic acid, 2,3-diketogulonic acid and oxalic acid (the reduced form of vitamin $\mathrm{C}$ ), it can be concluded that about 93\% of the vitamin C present in baobab pulp may be well absorbed.

The reported lowest and highest carbohydrate content of the pulp allows coverage of $21.5 \%$ and $40.6 \%$ of the RDI when $60 \mathrm{~g}$ is consumed by a child. The great variation in the reported iron, zinc, and calcium contents renders it difficult to estimate the contribution of baobab pulp to the RDI of these minerals. However, considering the highest reported values, the consumption of $40 \mathrm{~g}$ of baobab pulp is enough to cover $41.5 \%$ of the RDI for iron; $25.4 \%$ of the RDI for zinc, and $35 \%$ of the RDI for calcium. The energy content of the pulp is rather low when compared with the RDI for children.

A similar trend is observed for pregnant women (19-30 y). The consumption of $40 \mathrm{~g}$ of pulp by a pregnant woman will cover 84 to $141 \%$ of her RDI of vitamin C, considering the lowest and the highest vitamin $\mathrm{C}$ content of the pulp reported by authors. Moreover, a consumption of $100 \mathrm{~g}$ pulp will cover 26 to $50 \%$ of the carbohydrate RDI for pregnant women. As mentioned for the children, the coverage of iron, zinc, and calcium RDI is possible only when the highest reported values are considered for the pulp. Consumption of $60 \mathrm{~g}$ and $100 \mathrm{~g}$ would cover $23.1 \%$ and $38.4 \%$ of the RDI for iron; $17.3 \%$ and $28.7 \%$ of the RDI for zinc; $42.1 \%$ and $70.1 \%$ of the RDI for calcium; $30.2 \%$ and $50.3 \%$ of the RDI for carbohydrates, respectively. The energy content is also low for the RDI for pregnant women.

Table 10 Antioxidant capacity of baobab pulp compared to other fruits

Integral antioxidant capacity (IAC) corresponding to the sum of the corresponding water and lipid soluble antioxidants capacity

\begin{tabular}{ll}
\hline Products & $\begin{array}{c}\text { IAC (mmol Trolox equivalent/g fresh } \\
\text { weight, uncooked portion) }\end{array}$ \\
Baobab Fruit pulp & 11.1 \\
Baobab Dry leaves & 8.7 \\
Baobab Fruit glycolic extract & 1.02 \\
Baobab Leaves glycolic extract & 4.41 \\
Kiwi fruit pulp & 0.34 \\
Orange fresh pulp & 0.10 \\
Strawberry fresh pulp & 0.91 \\
Apple fresh pulp & 0.16 \\
\hline
\end{tabular}

Source: Vertuani et al. (2002)
There is no doubt that baobab pulp is a valuable source of vitamin C. If an added value would be given to the pulp by improving its handling, its quality, and storage stability using adequate processing methods, this might help to enhance interest about the pulp and lead to a better organization of this food chain in developing countries where the tree occurs and its food is well appreciated. At present, the preservation of the pulp, despite all its importance, is not properly controlled by the population, leading to undesirable losses. Subsequently, research is important to overcome problems in prolonging the shelf-life of the pulp in order to retain its nutritive value and sensorial properties. Bioavailability studies are necessary for a better appreciation of the contribution to human health since the dietary intake can never be fully utilized by the human body.

\section{Kernels}

The kernels are known for their high protein content. Consumption of $20 \mathrm{~g}$ can cover 15 to $34 \%$ of the protein RDI for children (Table 8), while for pregnant women $60 \mathrm{~g}$ can cover $27 \%$ of the RDI based on the highest reported content (Table 9). Moreover, consumption of $100 \mathrm{~g}$ can cover $22 \%$ of the energy RDI for pregnant women and $29.4 \%$ of energy RDI for children. Oil is extracted from the kernel and used for food and medicinal purposes. It is important to keep in mind that these data are related to the raw product and that further studies are required to evaluate the effect of cooking or other processing operations on the nutritive value of these products.

\section{Antioxidant Capacity of Pulp and Leaves}

Consuming antioxidant-rich foods can contribute to the prevention of oxidation in the human cell, hence of some diseases. In addition to the general chemical composition of baobab pulp and leaves discussed previously, Vertuani et al. (2002) investigated their antioxidant capacity and compared this with that of other common fruits (Table 10), using the photochemiluminescence method. They indicated that the antioxidant property of the pulp (measured as the Integral Antioxidant CapacityIAC - value) was 100 times higher than that of orange pulp. This antioxidant capacity may vary depending on the measuring method used, but the comparison with other fruits could still give similar trends. Cook et al. (1998) also investigated the antioxidant content of the aqueous extract of wild plants and found that baobab leaves have an antioxidant content of $7.7 \mu \mathrm{mol} / \mathrm{g}$ $\mathrm{dw}$ expressed as Trolox equivalents. This result is almost 1000 times lower than the one reported by Vertuani et al. (2002), who found that the water-soluble antioxidant capacity of dry baobab leaves was $6.4 \mathrm{mmol}$ Trolox equivalent/g.

These antioxidant activities were measured in fresh raw material and the effect of cooking and storage is not well known. Only Tarwadi and Agte (2005) investigated the antioxidative activity of some fruits and root vegetables before and after cooking. The antioxidant activity was measured as the inhibition 
of thiobarbituric acid reactive substances (TBARS), superoxide radical scavenging activity (SOSA), and ferrous iron chelating ability (FICA). They found that there were significant cooking losses for each of the assessed antioxidant parameters.

More research is needed on the antioxidative activity of baobab pulp and leaves during various processing operations, as well as the concentration of the related water soluble and fat-soluble compounds.

\section{CONCLUDING REMARKS}

From this literature review on baobab pulp, leaves, whole seeds, and kernels, it can be concluded that reported data show considerable variation although a fair number of investigations have been published about baobab products. We suggested some reasons to explain those variations. There is a lack of information on the vitamin content of baobab parts except for vitamin C. Whatever the variability, baobab pulp is apparently rich in vita$\min \mathrm{C}$, the leaves are rich in good quality proteins and minerals, and the kernels in fat. Most essential amino acids are present in the leaves. The pulp and the leaves also exhibit antioxidant activity. During future research, care should be taken to limit variability in collecting material, and in chemical analysis, and the data related to the environment of the samples should be described in detail. Further research is necessary to improve the quality and the shelf-life of the pulp, to investigate the antioxidant activity of the pulp and the leaves, to provide information about the bioavailability of macronutrients and micronutrients, and the effects of cooking and other processing techniques on the overall nutritional value of the products in order to improve present day practices as a measure to support the nutritional status of rural populations that incorporate baobab food products in their diet.

With respect to future research we recommend that:

1. More attention should be given to sampling, sample pretreatment, accuracy, and precision in analyses in order to get more reliable information about biological variation.

2. Nutritional research should focus on digestibility and bioavailability for a better nutritional evaluation of baobab products.

3. Detailed studies should be carried out on the effects of processing and storage on nutrient composition.

\section{REFERENCES}

Aitzetmüller, K. (1996). Intended use of Malvales seed oils in novel food formulations - a warning. Journal of the American Oil Chemists' Society. 73:17371738.

Ajayi, L. A., Dawodu, F. A., and Oderinde, R. A. (2003). Fatty acid composition and metal content of Adansonia digitata seeds and seed oil. La Rivisita Italiana Delle Sosteanze Grasse. 80:41-43.
Alverson, W. S., Whitlock, B. A., Nyffeler, R., Bayer, C., and Baum, D. A. (1999). Phylogeny of the core Malvales: Evidence from ndhF sequence data. American Journal of Botany. 86:1474-1486.

Andrianaivo-Rafehivola, A. A., Gaydou, E. M., and Rakotovao, L. H. (1994a). Revue sur les effets biologiques des acides gras cyclopropèniques, Oléagineux. 49:177-188.

Andrianaivo-Rafehivola, A. A., Cao, J., and Gaydou, E. E. (1994b). Effects of fresh and heated Baobab seed oil feeding on growth, food consumption and weight of some organs in rats. Revue Française des Corps Gras. 41:53-59.

Andy, E. O. H. and Eka, O. U. (1985). Nutritive value of leaves of baobab tree (Adansonia digitata). West African Journal of Biological and Applied Chemistry. 30:3-10.

Anonymous. (1998). Agronomic research in Mali identifies local sources of micronutrients. United Nations Systems Forum on Nutrition, Sub-committee on nutrition. SCN News. 17:71-73.

Arnold, T. H., Well, M. J., and Wehmeyer, A. S. (1995). Koisan food plants: taxa with potential for economic exploitation. In: Wickens, J. R., Goodin, and Field, D. V. Ed. Plants for Arid Lands. London: Allen and Unwin, pp. 69-86.

Assogbadjo, A. E., Kyndt, T., Sinsin, B., Gheysen, G., and Van Damme, P. (2006). Patterns of genetic and morphometric diversity in baobab (Adansonia digitata) populations across different climatic zones of Benin (West Africa). Annals of Botany. 97:819-830.

Barminas, J. T., Charles, M., and Emmanuel, D. (1998). Mineral composition of non-conventional leafy vegetables. Plant Foods for Human Nutrition. 53:2936.

Baum, D. A. (1995). A systematic revision of Adansonia (Bombacaceae). Annals of the Missouri Botanical Garden. 82:440-471.

Becker, B. (1983). The contribution of wild plants to human nutrition in the Ferlo (Northern Senegal). Agroforestry Systems. 1:257-267.

Boukari, I., Shier, N. W., Fernandez, X. E., Frisch, J., Watkins, B. A., Pawloski, L., and Fly, A. D. (2001). Calcium analysis of selected Western African foods. Journal of Food Composition and Analysis. 14:37-42.

Busson, F. (1965). Plantes Alimentaires de l'Ouest Africain, Etude botanique, biologique et chimique. Marseille, France: Leconte.

Carr, W. R. (1955). Ascorbic acid content of baobab fruit. Nature. 176:1273.

Carr, W. R. (1958). The baobab tree a good source of ascorbic acid. Central African Journal of Medicine. 4:372-374.

Codjia, J. T. C., Assogbadjo, A. E., and Ekué, M. R. M. (2003). Diversité et valorisation au niveau local des ressources forestières alimentaires végétales du Bénin. Cahiers Agriculture. 12:321-331.

Codjia, J. T. C., Fonton-Kiki, B., Assogbadjo, A. E., and Ekue, M. R. M. (2001). Le baobab (Adansonia digitata) Une espèce à usage multiple au Bénin, Cotonou, Bénin: Coco Multimédia.

Cook, J. A., Van der Jagt, D. J., Dasgupta, A., Mounkaila, G., Glew, R. S., Blackwell, W., and Glew, R. H. (1998). Use of the Trolox assay to estimate the antioxidant content of seventeen edible wild plants of Niger. Life Sciences. 63: $105-110$.

Diop, A. G., Sakho, M., Dornier, M., Cisse, M., and Reynes, M. (2005). Le baobab Africain (Adansonia digitata L.): principales caractéristiques et utilisations. Fruits. 61:55-69.

Eteshola, E. and Oraedu, A. C. I. (1996). Fatty acid compositions of tigernut tubers (Cyperus esculentus L), baobab seeds (Adansonia digitata L), and their mixture. Journal of the American Oil Chemists Society. 73:255-257.

Ezeagu, I. E., Petzke, K. J., Lange, E., and Metges, C. C. (1998). Fat content and fatty acid composition of oils extracted from selected wild-gathered tropical plant seeds from Nigeria. Journal of the American Oil Chemists Society. 75:1031-1035.

FAO/WHO/UNU, Energy and Protein Requirements. Reports of a joint FAO/WHO/UNU Expert Consultation, 1985.

Gaydou, E. M., Bianchini, J. P., and Ralaimanarivo, A. (1979). Huile de baobab africain: Adansonia digitata L. composition des acides gras et des sterols. Revue Francaise des Corps Gras. 26:447-448.

Ghani, A. and Agbejule, A. O. (1986). A pharmacognostic study of the fruits of Adansonia digitata L. In: Eds., Sofowora, A., The State of Medicinal Plant Research in Nigeria, Ife, Nigeria, University of Ife, pp. 181-185. 
Glew, R. H., Van der Jagt, D. J., Lockett, C., Grivetti, L. E., Smith, G. C., Pastuszyn, A., and Millson, M. (1997). Amino acid, fatty acid, and mineral composition of 24 indigenous plants of Burkina Faso. Journal of Food Composition and Analysis. 10:205-217.

Idouraine, A., Kohlhepp, E. A., and Weber, C. W. (1996). Nutrient constituents from eight lines of naked seed squash (Cucurbita pepo L.). Journal of Agricultural and Food Chemistry. 44:721-724.

Igboeli, L. C., Addy, E. O. H., and Salami, L. I. (1997). Effects of some processing techniques on the antinutrient contents of baobab seeds (Adansonia digitata). Bioresource Technology. 59:29-31.

Joyanes, M. and Lema, L. (2006). Criteria for optimizing food composition tables in relation to studies of habitual food intakes. Critical Reviews in Food Science and Nutrition. 46:329-336.

Li, D. and Sinclair, A. J. (2002). Macronutrient innovations: The role of fats and sterols in human health. Asia Pacific Journal of Clinical Nutrition. 11:S155S162.

Lockett, C. T. and Grivetti, L. E. (2000). Food-related behaviors during drought: a study of rural Fulani, northeastern Nigeria. International Journal of Food Sciences and Nutrition. 51:91-107.

Lockett, C. T., Calvert, C. C., and Grivetti, L. E. (2000). Energy and micronutrient composition of dietary and medicinal wild plants consumed during drought. Study of rural Fulani, Northeastern Nigeria. International Journal of Food Sciences and Nutrition. 51:195-208.

Maranz, S., Wiesman, Z., Bisgaard, J., and Bianchi, G. (2004). Germplasm resources of Vitellaria paradoxa based on variations in fat composition across the species distribution range. Agroforestry Systems. 60:71-76.

Murray, S. S., Schoeninger, M. J., Bunn, H. T., Pickering, T. R., and Marlett, J. A. (2001). Nutritional composition of some wild plant foods and honey used by Hadza foragers of Tanzania. Journal of Food Composition and Analysis. 13:1-11.

Nnam, N. M. and Obiakor, P. N. (2003). Effect of fermentation on the nutrient and antinutrient composition of baobab (Adansonia digitata) seeds and rice (Oryza sativa) grains. Ecology of Food and Nutrition. 42:265-277.

Nordeide, M. B., Hatløy, A., Følling, M., Lied, E., and Oshaug, A. (1996). Nutrient composition and nutritional importance of green leaves and wild food resources in an agricultural district, Koutiala, in Southern Mali. International Journal of Food Sciences and Nutrition. 47:455-468.

Nour, A. A., Magboul, B. I., and Kheiri, N. H. (1980). Chemical composition of baobab fruit (Adansonia digitata). Tropical Science. 22:383-388.

Obizoba, I. C. and Amaechi, N. A. (1993). The effect of processing methods on the chemical composition of baobab (Adansonia digitata L.) pulp and seed. Ecology of Food and Nutrition. 29:199-205.

Odetokun, S. M. (1996). The nutritive value of baobab fruit (Adansonia digitata). La Rivisita Italiana Delle Sosteanze Grasse. 73:371-373.

Oomen, H. A. P. C. and Grubben, G. J. H. (1978). Tropical leaf vegetables in human nutrition, Willemstad, Curacao: Royal Tropical Institute, Amsterdam and Orphan Publishing Company.

Osman, M. A. (2004). Chemical and nutrient analysis of baobab (Adansonia digitata) fruit and seed protein solubility. Plant Foods for Human Nutrition. 59:29-33.

Prentice, A., Laskey, M. A., Shaw, J., Hudson, G. J., Day, K. C., Jarjou, L. M. A., Dibba, B., and Paul, A. A. (1993). The calcium and phosphorus intakes of rural Gambian women during pregnancy and lactation. British Journal of Nutrition. 69:885-896.

Proll, J., Petzke, K. J., Ezeagu, I. E., and Metges, C. C. (1998). Low nutritional quality of unconventional tropical crop seeds in rats. Journal of Nutrition. 128:2014-2022.

Saka, J. D. K. and Msonthi, J. D. (1994). Nutritional value of edible fruits of indigenous wild trees in Malawi. Forest Ecology and Management. 64:245248.

Santos Oliveira, J. F. (1975). The nutritional value of some edible leaves used in Mozambique. Economic Botany. 29:256-264.

Scheuring, J. F., Sidibé, M., and Frigg, M. (1999). Malian agronomic research identifies local baobab tree as source of vitamin A and vitamin C. Sight of Life Newsletter. 1:21-24.

Sena, L. P., Van der Jagt, D. J., Rivera, C., Tsin, A. T. C., Muhamadu, I., Mahamadou, O., Millson, M., Pastuszyn, A., and Glew, R. H. (1998). Analysis of nutritional components of eight famine foods of the Republic of Niger. Plant Foods for Human Nutrition. 52:17-30.

Sidibe, M. and Williams, J. T. (2002). Baobab: Adansonia digitata, Southampton, UK: International Center for Underutilised Crops.

Sidibe, M., Scheuring, J. F., Tembely, D., Hofman, P., and Frigg, M. (1996). Baobab, homegrown vitamin C for Africa. Agroforestry Today. 8:13-15.

Smith, G. C., Clegg, M. S., Keen, C. L., and Grivetti, L. E. (1996). Mineral values of selected plant foods common to southern Burkina Faso and to Niamey, Niger, West Africa. International Journal of Food Sciences and Nutrition. 47:41-53.

Soloviev, P., Niang, T. D., Gaye, A., and Totte, A. (2004). Variabilité des caractères physico-chimiques des fruits de trois espèces ligneuses de cueillette, récoltés au Sénégal: Adansonia digitata, Balanites aegyptiaca et Tamarindus indica. Fruits. 59:109-119.

Tarwadi, K. and Agte, V. (2005). Antioxidant and micronutrient quality of fruit and root vegetables from the Indian subcontinent and their comparative performance with green leafy vegetables and fruits. Journal of the Science of Food and Agriculture. 85:1469-1476.

Vertuani, S., Braccioli, E., Buzzoni, V., and Manfredini, S. (2002). Antioxidant capacity of Adansonia digitata fruit pulp and leaves. Acta Phytotherapeutica. 5:2-7.

Wehmeyer, A. S. (1966). The nutrient composition of some edible wild fruits found in the Transvaal. South African Medical Journal. 40:1102-1104.

Wickens, G. E. (1982). The baobab - Africa's upside-down tree. Kew Bulletin. 37:173-209.

Yazzie, D., Van der Jagt, D. J., Pastuszyn, A., Okolo, A., and Glew, R. H. (1994). The amino acid and mineral content of baobab (Adansonia digitata L.) leaves. Journal of Food Composition and Analysis. 7:189-193.

\section{Websites}

http://www.fnri.dost.gov.ph/reni/renitable1.htm, 06-03-2006 http://www.iom.edu/CMS/3788.aspx, 07-03-2006 http://www.baobabfruitco.com, 07-03-2006 